\title{
Dolomitization of the Lower Ordovician Aguathuna Formation carbonates, Port au Port Peninsula, western Newfoundland, Canada: implications for a hydrocarbon reservoir
}

\author{
Karem Azmy, Denis Lavoie, lan Knight, and Guoxiang Chi
}

\begin{abstract}
The Lower Ordovician Aguathuna Formation ( $\sim 100 \mathrm{~m}$ thick) is formed of shallow-marine carbonates, which constitute the uppermost part of the St. George Group of western Newfoundland. Sedimentation was paused by a major subaerial exposure (St. George Unconformity), which likely developed a significant pore system in the underlying carbonates by meteoric dissolution. The sequence has been affected by multiphase dolomitization that caused complex changes in the rock porosity. The Aguathuna dolomites are classified into three main generations ranging in crystal size between $\sim 4 \mu \mathrm{m}$ and $2 \mathrm{~mm}$. The occurrence of fabric-retentive dolomicrites implies that dolomitization likely started during the early stages of diagenesis. Although dolomitization is pervasive in the upper part of the formation and significantly occludes the pores, some intervals in the lower part have higher porosity. The development of lower permeable layers overlain by an impermeable (seal) cap suggests a possible potential diagenetic trap. Unlike sabkha deposits, the Aguathuna carbonates do not have evaporite interlayers. Furthermore, the low $\mathrm{Sr}$ contents ( $96 \mathrm{ppm})$ and the $\delta^{18} \mathrm{O}$ values of earlier dolomites ( $-3.3 \%$ to $-6.9 \%$ VPDB (Vienna Pee Dee Belemnite)) are also difficult to reconcile with a brine origin. The $\mathrm{Sr} / \mathrm{Ca}$ molar ratios (0.0067-0.0009), calculated for the earliest dolomitizing fluid, suggest a modified seawater origin, likely mixed sea and meteoric waters. The least radiogenic ${ }^{87} \mathrm{Sr} /{ }^{86} \mathrm{Sr}$ values of the earliest dolomite are consistent with those of early Ordovician seawater, which supports an early-stage diagenesis. Petrography, geochemistry, and fluid inclusions of the late dolomites suggest precipitation at higher temperatures $\left(\sim 73-95^{\circ} \mathrm{C}\right)$ in deeper burial environments from hydrothermal solutions.
\end{abstract}

Résumé : La Formation d'Aguathuna (Ordovicien inférieur), d'une épaisseur $\sim 100 \mathrm{~m}$, est composée de carbonates marins d'eau peu profonde; ces carbonates constituent la partie supérieure du Groupe de St. George de l'Ouest de Terre-Neuve. La sédimentation a été arrêtée par une exposition subaérienne majeure (discordance de St. George), ce qui a vraisemblablement conduit au développement d'un important système de pores dans les carbonates sous-jacents par dissolution météorique. La séquence a été affectée par plusieurs phases de dolomitisation qui ont causé des changements complexes à la porosité de la roche. Les dolomites d'Aguathuna sont classifiées selon trois générations principales dont la dimension des cristaux varie de $\sim 4 \mu \mathrm{m}$ à $2 \mathrm{~mm}$. La présence de dolomicrites qui retiennent la texture implique que la dolomitisation a probablement débuté durant les premières phases de la diagenèse. Bien que la dolomitisation soit pénétrante dans la partie supérieure de la formation et ait bouché les pores de manière significative, quelques intervalles dans la partie inférieure ont une porosité plus élevée. Le développement de couches inférieures perméables sur lequel repose une couche imperméable (un scellement) suggère un potentiel piège diagénétique. Contrairement aux gisements de sebkha, les carbonates d'Aguathuna ne possèdent pas de couches interstratifiées d'évaporites. De plus, la faible teneur en $\mathrm{Sr}(\sim 96 \mathrm{ppm})$ et les valeurs $\delta^{18} \mathrm{O}$ des dolomites antérieures ( -3.3 to $-6.9 \%$ VPDB («Vienna Pee Dee Belemnite »)) sont difficiles à concilier avec une origine saumâtre. Les rapports molaires Sr/Ca $(0,0067-0,0009)$, calculés pour le fluide dolomitisant, suggèrent une origine d'eau de mer modifiée, probablement un mélange d'eau de mer et d'eau météorique. Les valeurs radiogéniques ${ }^{87} \mathrm{Sr} /{ }^{86} \mathrm{Sr}$ moindres de la dolomite la plus ancienne concordent avec celles de l'eau de mer à l'Ordovicien précoce, ce qui supporte une diagenèse de stage précoce. La pétrographie, la géochimie et les inclusions de fluides des dolomites tardives suggèrent une précipitation à partir de solutions hydrothermales à des températures plus élevées $\left(\sim 73-95^{\circ} \mathrm{C}\right)$ et dans des environnements d'enfouissement plus profonds.

[Traduit par la Rédaction]

Received 1 October 2007. Accepted 17 April 2008. Published on the NRC Research Press Web site at cjes.nrc.ca on 13 August 2008. Paper handled by Associate Editor J. Jin.

K. Azmy. ${ }^{1}$ Department of Earth Sciences, Memorial University of Newfoundland, St. John's, NL A1B 3X5, Canada.

D. Lavoie. Geological Survey of Canada, GSC-Q, Natural Resources Canada, 490 de la Couronne, QC G1K 9A9, Canada.

I. Knight. Geological Survey of Newfoundland and Labrador, Department of Natural Resources, Government of Newfoundland and Labrador, P.O. Box 8700, St. John's, NL A1B 4J6, Canada.

G. Chi. Department of Geology, University of Regina, Regina, SK S4S 0A2, Canada.

${ }^{1}$ Corresponding author (e-mail: kazmy@mun.ca). 


\section{Introduction}

The origin and distribution of dolomites in eastern North American Paleozoic reservoirs, particularly in the Ordovician (Arenig) carbonates of St. George Group of western Newfoundland and coeval strata nearby, have been the focus of many recent studies (Haywick 1984; Lane 1990; Cooper et al. 2001; Lavoie et al. 2005; and more references therein). Recently, hydrothermal dolomites have become a major target in the Appalachians and adjacent areas (cf. Lavoie et al. 2005; Lavoie and Chi 2006; Smith 2006).

Dolomitization of carbonate sediments is a significant diagenetic process that influences the porosity development and hence the hydrocarbon flow in strata. The Aguathuna carbonates, among the St. George Group carbonates of western Newfoundland, have been affected by significant karstification caused by intensive meteoric dissolution during their early diagenetic history (Knight 1991; Knight et al. 1991; Baker and Knight 1993; Langdon and Mireault 2004), due to a major subaerial exposure (St. George Unconformity). The early diagenetic pore system, developed by meteoric dissolution during this major exposure, increased the efficiency of a later stage multiphase dolomitization, which likely affected the overall rock porosity. The geological proximity of organic-rich shales (Green Point Formation of the Cow Head Group, possible potential hydrocarbon source rocks) and impermeable layers overlying the St. George Group (Table Point Formation limestone of the Table Head Group, seal rock), as well as the development of a thickskinned triangle zone during the Middle Devonian Acadian orogeny makes the sequence, and other equivalent Lower to Middle Ordovician carbonates in neighbouring areas, a potential candidate for oil accumulations (Fowler et al. 1995; Stockmal et al. 1998; Cooper et al. 2001). The general hydrothermal dolomite play concept (Davies and Smith 2006) applies well to the reservoir that was discovered in 1995 in the Port au Port Peninsula (Cooper et al. 2001). In early 2007, extended testing from the reservoir in the upper part of the St. George Group resulted in the production of high API (American Petroleum Institute) gravity $\left(50^{\circ}-56^{\circ}\right)$ oil (315 barrels per day) and significant volume of natural gas ( 1 million $\mathrm{ft}^{3} /$ day or $\sim 28317 \mathrm{~m}^{3} /$ day).

The current study investigates the diagenetic evolution of the Aguathuna carbonates that form the proven reservoir unit in the subsurface, the phases of dolomitization that affected the rocks, and how the resulting diagenetic framework control, reservoir characteristics and its potential for oil accumulations.

The main objectives of this project are to

(1) study the sedimentology and petrography of the Aguathuna Formation on the Port au Port Peninsula;

(2) investigate the diagenetic evolution and carbonate reservoir characterization of its dolostones; and

(3) identify (petrographically and geochemically) the dolomitization phases that influenced the rocks and the origin and nature of the dolomitizing fluids of each phase to understand the diagenetic controls on porosity development.

\section{Geologic setting}

Western Newfoundland is located within the northeast
Canadian Appalachian zone (Fig. 1), which has been intensively affected by complex orogenic events, particularly during the Paleozoic. The evolution of western Newfoundland shallow- to deep-marine lower Paleozoic continental margin successions has been discussed by several authors and recently refined and summarized by Cooper et al. (2001) and Lavoie (2008)

The inception of sedimentation along the newly formed Laurentia continent was related to the oldest rift event, dated at $615 \mathrm{Ma}$ (Kamo et al. 1989); however, Cawood et al. (2001) documented that significant rifting only started at $570 \mathrm{Ma}$ with a last pulse at 555-550 Ma (Waldron and van Staal 2001; van Staal 2005). In western Newfoundland, James et al. (1989) identified the end rift - early drift episode as the "pre-platform shelf" recorded by the Lower Cambrian Labrador Group. The pre-platform shelf was topped by a major clastic progradation event (the Hawke Bay event) in Early Cambrian (James et al. 1989). These clastic sediments were flooded by the following transgressive sea level, which led to the development of a thick carbonate platform succession known as the "Great American Bank" (Wilson et al. 1992). The carbonate-dominated passive margin of the Middle to Late Cambrian consisted of a narrow high-energy carbonate platform (Port au Port Group) that evolved into an Early to earliest Middle Ordovician wide, low-energy carbonate platform (St. George Group) (James et al. 1989). The passive margin period ended with onset of significant sea-floor subduction, which led to the migration of a tectonic peripheral bulge on the margin in earliest Middle Ordovician (Jacobi 1981; Knight et al. 1991). The migration of the tectonic peripheral bulge caused compression, block faulting, uplift, and erosion of the St. George carbonate platform. The subsequent subsidence contributed to mid-Darriwilian carbonate sedimentation (Table Point Formation; Stenzel et al. 1990). Continued subsidence led to deep-marine carbonate-shale and eventually to deep-marine shales. Early tectonic exhumation along the Round Head Precursor Fault (Waldron et al. 1993; Stockmal et al. 1998) resulted in local submarine erosion of tectonic escarpments and sedimentation of fault-scarp conglomerates (Cap Cormorant Formation). In late Darriwilian, the Taconian-derived foreland flysch (Mainland Sandstone of the Goose Tickle Group; Quinn 1995) was deposited on the foundered platform.

The St. George Group is a peritidal-dominated platform carbonate succession in western Newfoundland that was deposited during the Early Ordovician and has well exposed outcrops extending mainly along the western coast of Newfoundland (Fig. 1). The lithologic and structural frameworks of the basin, as well as the Paleozoic hydrocarbon systems data, suggest that the succession has potential economic hydrocarbon occurrences. Field observations of oil seeps in the area (e.g., Baker and Knight 1993) and of an exhumed oil field (Cooper et al. 2001) were strong evidence for hydrocarbon prospectivity of western Newfoundland. The successful drilling of the Port au Port \#1 well in 1995 (PaP1, Fig. 1) extended the evidence from surface outcrops to the subsurface realm. This led to the discovery of the Garden-Hill oil field at the west end of Port au Port Peninsula in the upper unit of the St. George Group by Hunt Oil and its partners (Newfoundland Hunt Oil Ltd, 1996 and Canadian Imperial Venture Corporation, 2007). 
Fig. 1. A photomosaic map at three scales of the study area showing the approximate location of the investigated drill hole RND1 on Port au Port Peninsula in western Newfoundland (Google Earth).

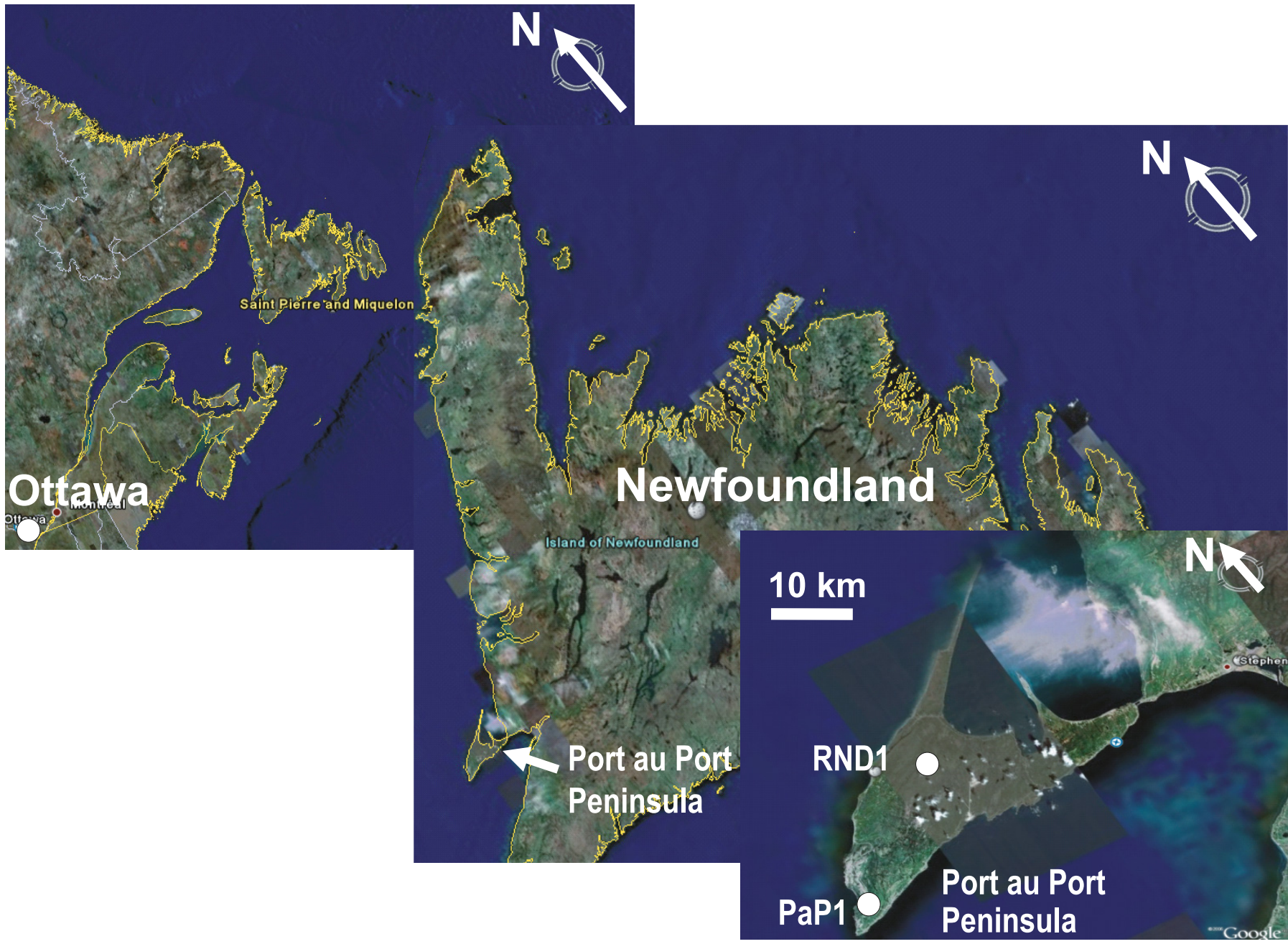

\section{Methodology}

The core from drill hole RND1 (Westminer Canada Ltd. 1992; longitude $59^{\circ} 02^{\prime} 37^{\prime \prime} \mathrm{W}$, latitude $48^{\circ} 36^{\prime} 43^{\prime \prime} \mathrm{N}$ ) from the west end of Port au Port Peninsula penetrates the thickest succession of the Aguathuna Formation ( 97 m, Fig. 2) in western Newfoundland (Knight et al. 2007). The core RND1 was logged and sampled at high resolution (Appendix A). It was carefully selected not only to have the maximum formation thickness but also to avoid the tectonic complications (e.g., extensive faulting) in the area. Thin sections of the samples were examined petrographically under standard polarizing microscope and cathodoluminoscope and stained with Alizarin Red-S and potassium ferricyanide solutions (Dickson 1966). A mirror-image slab of each thin section was also prepared and polished to be utilized for microsampling. Cathodoluminescence (CL) was performed using an ELM-3R cold cathode instrument operated at $\sim 12 \mathrm{kV}$ accelerating voltage and $\sim 0.7 \mathrm{~mA}$ gun current intensity. Fluid-inclusion microthermometry was conducted on double polished thick sections, using a calibrated Linkam THMSG 600 at the Geofluids Laboratory of the University of Regina, Regina, Saskatchewan. The precision is $\pm 0.2{ }^{\circ} \mathrm{C}$ for melting temperature and $\pm 1{ }^{\circ} \mathrm{C}$ for homogenization temperature measurements. Salinities were calculated using a program by $\mathrm{Chi}$ and $\mathrm{Ni}$ (2007) for the system of $\mathrm{H}_{2} \mathrm{O}-\mathrm{NaCl}-\mathrm{CaCl}_{2}$.

Permeability was measured in samples by utilizing a computer controlled probe steady-state permeameter, Temco Model MP-401. The probe tip was placed at least $1 \mathrm{~cm}$ from any of the sample edges and pressed at $\sim 16 \mathrm{psi}$ $(\sim 110 \mathrm{kPa})$. The volumetric flow rate was adjusted to be approximately constant and relatively low ( $\left.\leq 100 \mathrm{~cm}^{3} / \mathrm{min}\right)$.

Polished slabs were washed with deionized water and dried overnight at $50{ }^{\circ} \mathrm{C}$ prior to the isolation of samples of the different dolomite generations and calcite cements. Approximately $4 \mathrm{mg}$ were microsampled from the cleaned slabs with a low-speed microdrill. For C- and O-isotope analyses, about $220 \mu \mathrm{g}$ of powder sample was reacted in inert atmosphere with ultrapure concentrated (100\%) orthophosphoric acid at $70{ }^{\circ} \mathrm{C}$ in a Thermo Finnigan Gasbench II and the produced $\mathrm{CO}_{2}$ was automatically delivered to the source of a Thermo Finnigan DELTA V plus (Thermo Finnigan is now part of Thermo Fisher Scientific) isotope ratio mass spectrometer in a stream of helium, where the gas was ionized and measured for isotope ratios. Uncertainties of better than $0.1 \%$ o $(2 \sigma)$ for the analyses were determined by repeated measurements of stable isotope standards NBS-19 
Fig. 2. Lithostratigraphy of the Aguathuna Formation exhibited by the studied Core RND1 and correlation with the field section on Port au Port Peninsula. Few very thin (centimetre-scale) shale interbeds occur in the succession but do not show on the figure due to scale limits. See text for detail (modified from Knight et al. 2007).

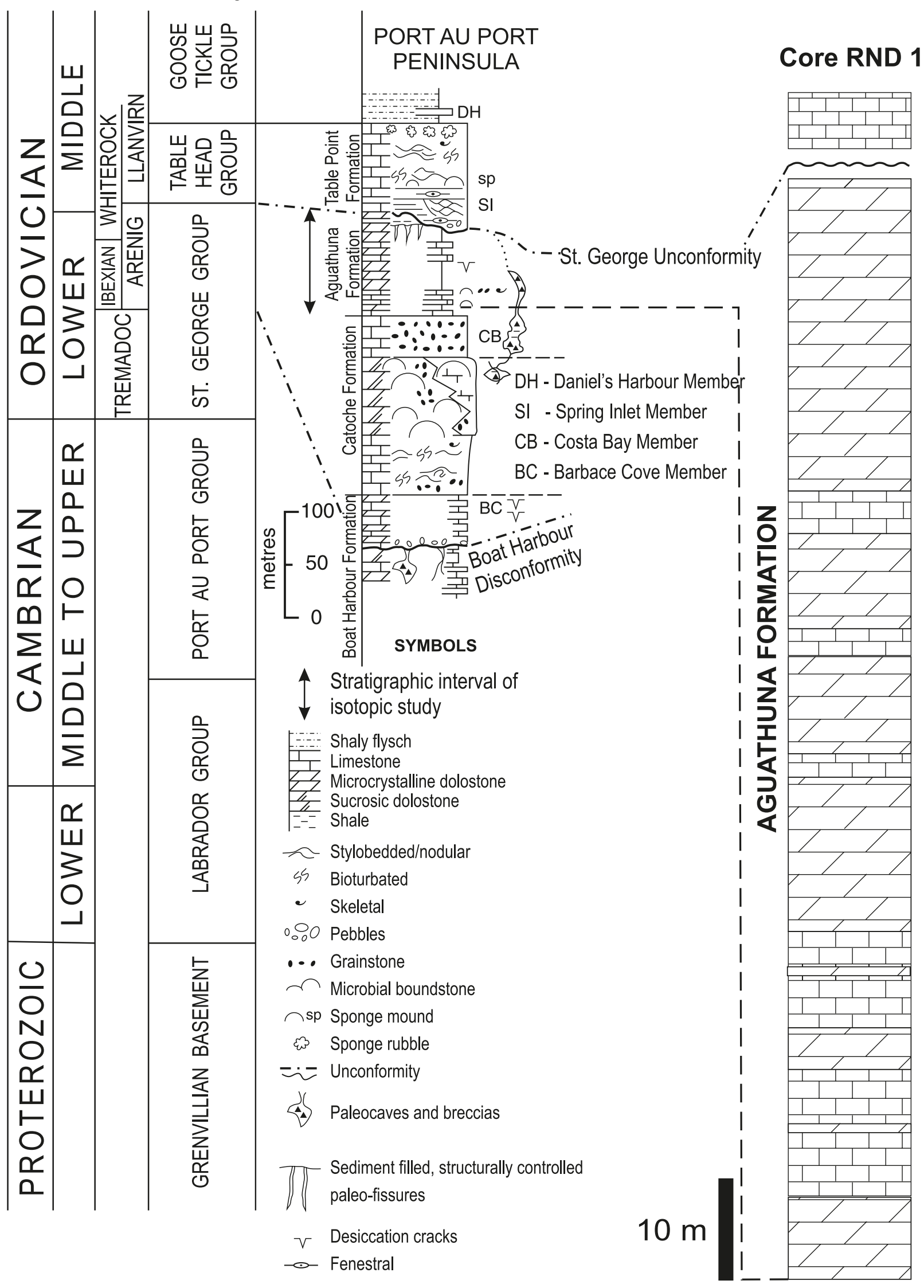


$\left(\delta^{18} \mathrm{O}=-2.20 \%\right.$ and $\delta^{13} \mathrm{C}=+1.95 \%$ vs. VPDB $)$ and LSVECS $\left(\delta^{18} \mathrm{O}=-26.64 \%\right.$ and $\delta^{13} \mathrm{C}=-46.48 \%$ vs. VPDB $)$, as well as internal standards.

For elemental analyses, a subset of sample powder was digested in $2.5 \%(v / v)$ pure $\mathrm{H}_{3} \mathrm{PO}_{4}$ acid for 70-80 min and analyzed for $\mathrm{Ca}, \mathrm{Mg}, \mathrm{Sr}, \mathrm{Mn}$, and $\mathrm{Fe}$ (Coleman et al. 1989) using a HP 4500plus inductively coupled plasma - mass spectrometry (ICP-MS) at Memorial University of Newfoundland, St. John's, Newfoundland. The relative uncertainties of these measurements are better than $5 \%$.

Guided by petrographic observations, cold cathodoluminoscope examinations, and the carbon and oxygen isotope results, a subset of samples representing different dolomite generations was selected for Sr-isotope analysis. About $1 \mathrm{mg}$ of the powdered sample was dissolved in $2.5 \mathrm{~N}$ ultrapure $\mathrm{HCl}$ and, after evaporation, $\mathrm{Sr}$ was extracted with quartz glass exchange columns filled with Bio Rad AG50WX8 ion exchange resin. Finally, 100 ng $\mathrm{Sr}$ was loaded on $\mathrm{Re}$ filaments using a $\mathrm{Ta}_{2} \mathrm{O}_{5}-\mathrm{HNO}_{3}-\mathrm{HF}-\mathrm{H}_{3} \mathrm{PO}_{4}$ solution. Measurements were performed with a Finnigan MAT 262 multicollector mass spectrometer at the Institut für Geologie, Mineralogie und Geophysik, Ruhr Universität, Bochum, Germany (e.g., Azmy et al. 1999, 2001 and references therein).

Two standard reference materials were utilized as quality control of Sr-isotope ratio measurements, NBS 987 (mean $\left.{ }^{87} \mathrm{Sr} /{ }^{86} \mathrm{Sr}=0.709159 \pm 0.000004, n=72\right)$ and USGS EN-1 $\left(\right.$ mean $\left.{ }^{87} \mathrm{Sr} /{ }^{86} \mathrm{Sr}=0.710238 \pm 0.000005, n=72\right)$. The ${ }^{87} \mathrm{Sr} /$ ${ }^{86} \mathrm{Sr}$ measurements were normalized to NBS 987 values bracketing the samples $(0.710247)$ and corrected for deviation from value stated by McArthur (1994).

\section{Lithostratigraphy}

The lithostratigraphy of the St. George Group has been discussed and refined by several authors (e.g., Pratt and James 1986; Knight and James 1987; Knight 1991; Baker and Knight 1993; Cooper et al. 2001; Knight et al. 2007). The group consists of Early Ordovician (Tremadoc-Arenig) platform carbonates, which, in ascending order, include the Watts Bight, Boat Harbour, Catoche, and Aguathuna formations (Fig. 2). The top of the St. George Group (Aguathuna - Table Point formations contact) is marked by the major regional St. George Group Unconformity, which formed in response to the passage of a Taconic peripheral forebulge across the platform at a time of a major sea level lowstand (Mussman and Read 1986; Knight et al. 1991; Lavoie 1994; Cooper et al. 2001). Significant regional erosion occurred at the level of the St. George Unconformity, and karstification below it likely enhanced the porosity in underlying carbonate rocks, a close analogue to the Ellenburger Group in West Texas (Kerans 1989; Loucks 2003).

The St. George Group is divisible into two, long-lived 3rd-order sequences of Tremadocian and Arenigian age; Knight and James (1987) referred to the sequences as megacycles. Each megacycle is a sequence of deepening to shallowing upward and is characterized by a structure of generally lower peritidal, middle subtidal, and upper peritidal units (Knight and James 1987). The younger Arenigian sequence is bounded by the Boat Harbour disconformity at the base and by the St. George Unconformity at the top
Fig. 3. Paragenetic sequence of the Aguathuna Formation showing relative timing of tectono-diagenetic events. The succession of events is based on conventional and cathodoluminescence petrographic relationships and on some geochemical data.

\begin{tabular}{|c|c|c|c|c|}
\hline \multirow[t]{2}{*}{ Feature } & \multirow[t]{2}{*}{ Marine } & \multirow[t]{2}{*}{ Meteoric } & \multicolumn{2}{|c|}{ Burial } \\
\hline & & & Shallow & Deep \\
\hline $\begin{array}{l}\text { Marine deposition }(\mathrm{C} 1) \& \\
\text { fibrous cements }(\mathrm{Cfb})\end{array}$ & & & & \\
\hline $\begin{array}{l}\text { Uplift \& meteoric equant } \\
\text { Cements (C2) }\end{array}$ & & 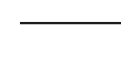 & & \\
\hline Dolomite 1 (D1) & & & & \\
\hline Solution seams & & & & \\
\hline Dolomite 2 (D2) & & & & \\
\hline Stylolites & & & & \\
\hline Vertical fractures & & & & \\
\hline Saddle dolomite (D3) & & & & \\
\hline Pyrite mineralization & & & & Phase 1 \\
\hline Fracture-filling calcite (C3) & & & & \\
\hline Pyrite mineralization & & & & Phase 2 \\
\hline Silicification & & & & \\
\hline
\end{tabular}

(Fig. 2). It comprises the Barbace Cove Member of the Boat Harbour Formation (lower peritidal), the Catoche Formation (middle subtidal), and the Aguathuna Formation (upper peritidal). Field observations suggest that regional erosion below the St. George Unconformity might have locally removed up to $60 \mathrm{~m}$ or more strata of the Aguathuna Formation (cf. Knight and James 1987; Knight et al. 2007).

The Aguathuna Formation is a unit of metre-scale, peritidal cyclic carbonate, which is mapped throughout the autochthon of western Newfoundland. In many parts of northwestern Newfoundland, it is exclusively finely crystalline dolostone and minor shale (Knight and James 1987). On the Port au Port Peninsula, however, limestone is intercalated with the dolostone and shale. This is typical of the succession logged in drill hole RND1 (Fig. 2). Limestone forms marker units $2-5 \mathrm{~m}$ thick in the lower $85 \mathrm{~m}$ of the formation (Knight et al. 2007). Several thin beds of limestone 10$100 \mathrm{~cm}$ thick also occur isolated within thick dolostones that exhibit similar depositional fabrics. Limestone is more common in the lower part of the formation above the shale (at $85 \mathrm{~m}$ mark of RND1); the unit is almost exclusively dolostone. Small vestiges of limestone bounded by irregular surfaces occurring a few metres from the top of the formation in drill hole RND1 are probably remnants of limestone interbeds that were incompletely dissolved (Knight et al. 2007). In the eastern sector of the peninsula, limestone beds disappear between sections only a few kilometres apart, and their stratigraphic position is replaced by bedding plane caves (Knight et al. 1991; their fig. 14).

The Aguathuna limestones range from burrow-mottled, unfossiliferous, lime mudstones and wackestone to fossiliferous and peloidal wackestones and packstones; skeletal, peloidal, oolitic, and oncolitic grainstones and floatstones; intraclastic rudstones and stromatolitic boundstones. Trilobites, brachiopods, and ostracods are recognized in the fossiliferous limestones of the cores.

The dolostones of the formation are characterized by burrow-mottled, stromatolitic patterned and laminated deposi- 
tional fabrics. Mudcracks, small tepee structures, rare white cauliflower quartz nodules, cross lamination, thin beds of dolorudstone, and local pockets of intraformational breccia characterize the dololaminites. Green and green-grey shales occur scattered as partings and centimetre-thick beds mostly associated with the dololaminites.

\section{Petrography, diagenesis, and paragenetic sequence}

Petrographic examination of the limestones of Aguathuna Formation from Core RND1 reveals 1-2 m thick beds that are dominated by muddy carbonates. They vary between peloidal and algal laminated fenestral to thrombolitic microbial lime mudstones and wackestones that are commonly dolomitized (e.g., Knight and James 1987; Knight et al. 2007). Bioclastic grainstones, although uncommon, occur in the upper part of the formation. Dolostones are dominantly fabric-retentive dolomicrite to finely crystalline dolomites. Coarse saddle dolomite phases are only found in a few vugs in the lower part of the formation.

The paragenetic sequence of events that affected the sediments is summarized in Fig. 3. It is based on petrographic observations (conventional optical and CL), spatial distribution, crosscutting relationships among depositional and diagenetic fabrics, such as cements, stylolitization, and fracturing. The diagenetic processes that affected the Aguathuna sediments can be related to four main stages (Fig. 3): marine, subaerial exposure and meteoric, shallow-burial, and deep-burial diagenesis.

Near-surface (marine) diagenesis accompanied the deposition of micrite and micritic algae (C1), skeletal components, and accretion of sediments. It is supported by the occurrence of the isopachous fibrous $(\mathrm{Cfb})$ marine cements (Figs. $4 a$, $4 b)$ with internal sediments and microborings.

Marine sedimentation was terminated by the major subaerial exposure at the St. George Unconformity (Knight et al. 1991). It resulted in karstification and development of an early secondary dissolution pore system that extended down into the underlying Aguathuna and Catoche carbonates (Baker and Knight 1993; Cooper et al. 2001). Non-luminescent meteoric equant cements $(\mathrm{C} 2)$ precipitated below water table in some of the interparticle pore spaces (Figs. $4 a, 4 b$ ). Progressive burial of the St. George Group carbonates occurred with sea level rise and deposition of younger carbonate sediments of the overlying Table Head Group. Early compactional features, such as in situ broken fragments, close-packed grains, fitted fabrics, and microstylolites (Fig. 4c), formed at shallow depths in the early stages of burial. An early phase of pervasive fabric-retentive dolomitization affected mainly the micritic matrix (Fig. 4d), which seems to have occurred during the early stages of burial diagenesis (e.g., Lane 1990). As a result of increasing compaction, higher amplitude stylolites (Fig. 4c) developed and later stage dolomitization occurred, which resulted in the precipitation of CL-zoned replacive (D2) dolomites (Figs. $4 f, 4 g$ ). The second phase of dolomitization generated intercrystalline pores with sharp boundaries that mimic the crystal faces (Fig. 4f). The latest dolomite generation (D3), which exhibits sweeping extinction (Fig. 4h), is also associated with pyrite mineralization and occludes some of the pores. At deeper burial, vertical fractures developed and were subsequently filled with the latest calcite (C3) cements, which engulf coarse euhedral pyrite crystals (Fig. 4d). The investigated samples do not show a clear petrographic relationship between C3 and D3. A minor phase of silicification occurred at the latest stages of diagenesis after the saddle dolomite (D3).

\section{Results}

\section{Dolomitization}

The Aguathuna Formation carbonates are almost entirely dolomitized and the current study, therefore, focuses on the dolomitization process that influenced the rocks. Based on petrography and CL, three major phases of dolomitization have been recognized. From oldest to the youngest, these are Dolomite 1 (D1, pervasive dolomite), Dolomite 2 (D2, equant replacive dolomite), and Dolomite 3 (D3, large equant pore-filling to replacive saddle dolomite).

Dolomite 1 (Fig. $4 d$ ) is abundant in most beds ( $\sim 70 \%$ by volume), consists of inclusion-rich pervasive xenotopic dolomite (cf. Budd 1997), and exhibits dull to no luminescence (cf. Machel and Mountjoy 1986, 1990) under CL (Fig. 4e). D1 is a mimetic and, in many cases, fabric-preserving dolomite (cf. Budd 1997) with crystal sizes varying approximately between micrite and microsparite (up to $\sim 30 \mu \mathrm{m}$ ).

Dolomite 2 consists of relatively coarse equant sub- to euhedral crystals ( $\sim 20 \%$ by volume) of a progressive stage of replacement and recrystallization but rarely pore-filling dolomite (e.g., Lonnee and Machel 2006; Wierzbicki et al. 2006). The crystals vary in size between $\sim 60$ and $200 \mu \mathrm{m}$ and exhibit cloudy cores with, in places, clear rims under plane-polarized light (Fig. 4f), but zoned luminescence (Fig. 4g) under CL. Although inclusions in dolomites are usually relics of possible clays (e.g., Azmy et al. 2001) or precursor carbonates (Sibley 1982; Budd 1997), staining of the examined dolomites does not reveal any traces of calcite, which may suggest that these inclusions are most likely clays. This dolomite postdates D1 but is assumed to have formed likely at shallow-burial depth since it is crosscut by solution seams and microstylolites.

Dolomite 3 occludes many pores, and it is interpreted as the latest stage of dolomitization likely under deep-burial conditions (e.g., White and Al-Aasm 1997). It consists of pore-filling and replacive coarse sub- to anhedral crystals $(0.5-2 \mathrm{~mm})$ with a distinctive milky appearance in polished thin sections and polished slabs. Dolomite 3 is generally uncommon throughout the Aguathuna Formation, but mainly occurs in the lowermost stratigraphic intervals in the core samples (Appendix A). The pore-filling crystals are relatively clear, but the replacive crystals are cloudy. Both pore-filling and replacive crystals usually exhibit undulose extinction (Fig. 4h), typical of saddle dolomites, and appear dull under CL (e.g., Azmy et al. 2001; Al-Aasm 2003; AlAasm and Clarke 2004).

\section{Fluid inclusions}

Primary fluid inclusions were studied in D2, D3, and C3 (cf. Goldstein and Reynolds 1994), and they provide consistent homogenization temperatures $(T \mathrm{~h})$ for each phase (Table 1). Because fluid inclusions are studied mainly in cements, D1 crystals (mainly dolomicrite) were too small and 
Fig. 4. Some of the diagenetic features of the Aguathuna carbonates. (a) Photomicrograph under plane-polarized light of a thin section of algal grainstone (sample R1-158); arrows point at the fibrous isopachous cement (Cfb) and early equant cement (C2). (b) Cathodoluminoscope image of $(a)$ showing non-luminescent marine isopachous and meteoric equant cements. $(c)$ Photograph of a polished slab (sample R1-138) showing solution seams (upper arrow) and a higher amplitude stylolite (lower arrow); the dots are microdrilled zones for geochemical analyses. (d) Photomicrograph under plane-polarized light of a thin section (sample R1-102) of dense dolomicrite (D1) crosscut by a fracture filled with the latest calcite cement (C3) engulfing large pyrite (py) crystals. $(e)$ Cathodoluminoscope image of $(d)$ showing nonluminescent to dull D1 and bright luminescent C3. (f) Photomicrograph under plane-polarized light of a thin section (sample R1-170) of dolomite 2 (D2), showing intercrystalline (white arrows) and vuggy (black arrow) pores. ( $g$ ) Cathodoluminoscope image showing CL-zonation in D2 crystals. (h) Photomicrograph under crossed Nicols of a thin section of saddle dolomite 3 (D3) showing typical undulose extinction (sample R1-148); arrow points at microvugs developed in D1.
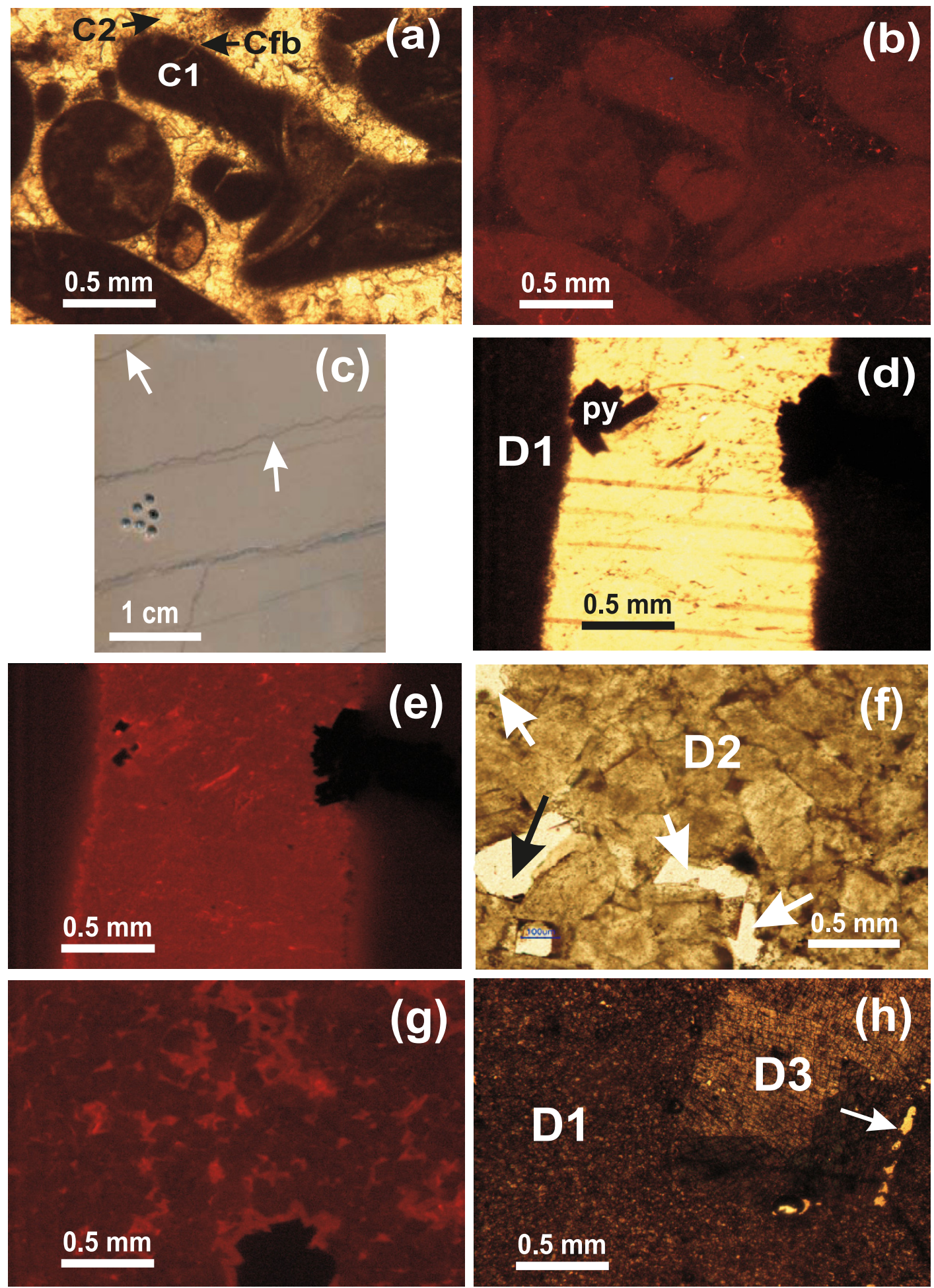
Table 1. Summary of fluid-inclusion microthermometric data of the Aguathuna carbonates.

\begin{tabular}{|c|c|c|c|c|c|c|c|c|}
\hline Sample ID & Host mineral & Occurrence & Size $(\mu \mathrm{m})$ & Vapor $\%$ & Tm-first $\left({ }^{\circ} \mathrm{C}\right)$ & $T \mathrm{~m}-\mathrm{H}_{2} \mathrm{O}\left({ }^{\circ} \mathrm{C}\right)$ & Th $\left({ }^{\circ} \mathrm{C}\right)$ & Salinity (wt.\%) \\
\hline \multirow[t]{12}{*}{ R1-147.8 } & \multirow[t]{11}{*}{ D3 } & Random & 6 & 5 & - & & 93.0 & - \\
\hline & & Random & 7 & 5 & -57 & -31.3 & 101.0 & 26.2 \\
\hline & & Random & 7 & 5 & -53 & -29.5 & 98.0 & 25.7 \\
\hline & & Random & 12 & 5 & -66 & -19.2 & 96.0 & 21.8 \\
\hline & & Random & 6 & 5 & - & -19.0 & 94.0 & 21.7 \\
\hline & & \multirow[t]{3}{*}{ Random } & 13 & 5 & -66 & -29.5 & 88.0 & 25.7 \\
\hline & & & 12 & 5 & - & -18.8 & 92.0 & 21.5 \\
\hline & & & 14 & 5 & -60 & -18.9 & 87.0 & 21.6 \\
\hline & & Random & 18 & 5 & -64 & -17.4 & & 20.5 \\
\hline & & Random & 8 & 10 & - & -17.8 & 91.0 & 20.8 \\
\hline & & Random & 9 & 10 & -60 & -19.2 & 93.0 & 21.8 \\
\hline & D2 & Isolated & 6 & 5 & - & -26.7 & 69.0 & 24.8 \\
\hline \multirow[t]{6}{*}{ R1-148 } & \multirow[t]{6}{*}{ D3 } & Random & 18 & 10 & -59 & -26.2 & 108.0 & 24.7 \\
\hline & & Random & 8 & 5 & - & -19.6 & & 22.1 \\
\hline & & Random & 20 & 5 & -62 & -26.0 & 105.0 & 24.6 \\
\hline & & Random & 6 & 5 & - & - & 91.0 & - \\
\hline & & Random & 19 & 5 & -59 & -24.0 & & 24.0 \\
\hline & & & 14 & 5 & -58 & -18.1 & & 21.0 \\
\hline \multirow[t]{13}{*}{ R1-102 } & \multirow[t]{13}{*}{$\mathrm{C} 3$} & Isolated & 7 & 5 & -53 & -19.1 & 76.0 & 21.8 \\
\hline & & & 4 & 5 & - & -19.3 & 78.0 & 21.9 \\
\hline & & Isolated & 4 & 5 & - & -19.4 & 79.0 & 22.0 \\
\hline & & Isolated & 5 & 5 & - & -16.1 & 74.0 & 19.5 \\
\hline & & & 7 & 3 & -57 & -16.3 & 76.0 & 19.7 \\
\hline & & Isolated & 14 & 3 & -60 & -16.1 & 71.0 & 19.5 \\
\hline & & Isolated & 5 & 5 & - & -18.7 & 68.0 & 21.5 \\
\hline & & & 3 & 5 & - & - & 67.0 & - \\
\hline & & Isolated & 10 & 5 & -56 & -24.5 & 73.0 & 24.2 \\
\hline & & Isolated & 9 & 5 & - & -19.2 & 72.0 & 21.8 \\
\hline & & Isolated & 5 & 5 & - & -19.4 & 74.0 & 22.0 \\
\hline & & Isolated & 6 & 5 & - & -19.6 & 69.0 & 22.1 \\
\hline & & Isolated & 7 & 5 & -58 & -19.8 & 71.0 & 22.2 \\
\hline \multirow[t]{22}{*}{ R1-116 } & \multirow[t]{6}{*}{ D2 } & Random & 6 & 5 & - & & 69.0 & - \\
\hline & & & 3 & 5 & - & & 73.0 & - \\
\hline & & Random & 7 & 5 & - & & 78.0 & - \\
\hline & & Random & 4 & 5 & - & -17.2 & 72.0 & 20.4 \\
\hline & & Random & 4 & 5 & - & & 77.0 & - \\
\hline & & & 2 & 5 & $\mathrm{v}$ & & 74.0 & - \\
\hline & \multirow[t]{16}{*}{$\mathrm{C} 3$} & Isolated & 12 & 3 & - & - & 80.0 & - \\
\hline & & & 8 & 3 & -55 & -24.4 & 70.0 & 24.1 \\
\hline & & Isolated & 7 & 3 & - & - & 74.0 & - \\
\hline & & Isolated & 13 & 2 & -59 & -22.1 & 67.0 & 23.5 \\
\hline & & Isolated & 6 & 5 & -57 & -23.5 & 76.0 & 23.9 \\
\hline & & Cluster & 6 & 3 & - & - & 78.0 & - \\
\hline & & & 3 & 3 & - & - & 74.0 & - \\
\hline & & & 5 & 3 & - & -20.0 & 78.0 & 22.4 \\
\hline & & Isolated & 9 & 3 & -62 & -22.4 & 82.0 & 23.6 \\
\hline & & Isolated & 15 & 3 & -50 & -21.2 & 71.0 & 23.2 \\
\hline & & Isolated & 8 & 5 & - & -23.5 & 72.0 & 23.9 \\
\hline & & & 6 & 5 & -58 & -23.8 & 75.0 & 24.0 \\
\hline & & Isolated & 3 & 5 & - & - & 67.0 & - \\
\hline & & & 4 & 5 & - & - & 64.0 & - \\
\hline & & Isolated & 8 & 5 & - & -22.4 & 71.0 & 23.6 \\
\hline & & Isolated & 5 & 5 & - & -23.9 & 79.0 & 24.0 \\
\hline
\end{tabular}

Note: Tm, ice-melting temperatures.

had no fluid inclusions for measurement. The microthermometric data are listed in Table 1 and illustrated in Figs. 5a, $5 b$. The fluid inclusions in D2 yielded a range of $T$ h from 69 to $78{ }^{\circ} \mathrm{C}$ (average $=73{ }^{\circ} \mathrm{C}, n=6$ ) and final ice-melting temperatures $\left(\mathrm{Tm}\right.$ ) from -26.2 to $-17.2{ }^{\circ} \mathrm{C}$ (average $=-21.7{ }^{\circ} \mathrm{C}$, $n=2$ ), with corresponding salinities from 20.4 to 24.8 wt. $\%$ 
(average $=22.6 \mathrm{wt} . \%, n=2$ ). Fluid inclusions in D3 have Th from 87 to $108{ }^{\circ} \mathrm{C}$ (average $\left.=95{ }^{\circ} \mathrm{C}, n=13\right)$, final $(T \mathrm{~m})$ from -31.3 to $-17.4{ }^{\circ} \mathrm{C}$ (average $=-22.3{ }^{\circ} \mathrm{C}, n=15$ ), and salinities from 20.8 to 26.2 wt.\% (average $=23.3, n=15$ ). Relatively abundant fluid inclusions are measurable in $\mathrm{C} 3$, giving $T$ h from $64^{\circ}$ to $82{ }^{\circ} \mathrm{C}$ (average $=73, n=29$ ), final (Tm) from $-24.5^{\circ}$ to $-16.1{ }^{\circ} \mathrm{C}$ (average $=-20.7{ }^{\circ} \mathrm{C}, n=22$ ), and salinities from 19.5 to 24.2 wt. $\%$ (average $=22.5$ wt. $\%$, $n=22$ ). As shown in Fig. $5 b$, the salinities are similar for D2, D3, and C3. The homogenization temperatures are similar between D2 and C3, but those in D3 are significantly higher (Figs. $5 a, 5 b)$.

\section{Major and trace elements}

Table 2 summarizes the major and trace element concentrations in the different non-skeletal carbonate components (mainly cements) in the Aguathuna carbonates. The Aguathuna dolomites (D1 to D3) have Ca concentrations ranging from $\sim 53 \%$ to $68 \%$ (Table 2). Some elements, such as Mn and $\mathrm{Fe}$, are generally enriched in the diagenetic phase during post-depositional processes, whereas others, such as $\mathrm{Sr}$, are depleted (Veizer 1983). The Mn concentrations of the Aguathuna carbonate phases increase from $78 \pm 66 \mathrm{ppm}$ in limemud $(\mathrm{C} 1)$ to $1218 \pm 721 \mathrm{ppm}$ in the latest fracture-filling cement (C3), and those of Fe from $710 \pm 434$ to $891 \pm$ 418 ppm (Table 2; Fig. 6a) for the same phases. Similarly, the $\mathrm{Mn}$ content of the dolomites increases from $314 \pm$ $230 \mathrm{ppm}$ in D1 to $1555 \pm 530 \mathrm{ppm}$ in D3 and Fe content from $1795 \pm 1117$ to $7690 \pm 1153 \mathrm{ppm}$ (Table 2 and Fig. 6a). In contrast, the $\mathrm{Sr}$ concentrations show an opposite trend and decrease from $300 \pm 154 \mathrm{ppm}$ in $\mathrm{C} 1$ to $76 \pm$ $15 \mathrm{ppm}$ in $\mathrm{C} 3$ (Fig. 6b) and from $92 \pm 18 \mathrm{ppm}$ in D1 to $52 \pm 12 \mathrm{ppm}$ in D3.

\section{Oxygen and carbon isotopes}

The C- and O-isotope compositions of the Aguathuna carbonates are summarized in Table 2. The $\delta^{13} \mathrm{C}$ and $\delta^{18} \mathrm{O}$ values of the Aguathuna calcites decrease from $-1.3 \% \pm$ $0.8 \%$ and $-7.1 \%$ $\pm 0.6 \%$ (VPDB) in $\mathrm{C} 1$ to $-3.0 \%$ \pm $0.3 \%$ and $-10.9 \%$ $\pm 2.0 \%$ (VPDB) in $\mathrm{C} 3$, respectively. The mean $\delta^{13} \mathrm{C}$ values of the Aguathuna dolomite phases (D1 to D3) do not show a significant variation (Table 2) but are within a narrow range of $\sim 0.6 \%$. However, the mean $\delta^{18} \mathrm{O}$ values (Table 2) decrease from $-4.0 \% \pm 0.6 \%$ (VPDB) in D1 to $-5.6 \% \pm 0.2 \%$ (VPDB) in D2, although that of D3 $(-3.5 \% \pm 0.2 \%)$ is slightly higher (Fig. 7).

\section{Strontium isotopes}

The earliest phase of dolomites (D1) yielded ${ }^{87} \mathrm{Sr} /{ }^{86} \mathrm{Sr}$ values between $0.709251 \pm 0.000009$ and $0.712434 \pm$ 0.000010 (Fig. 8; Appendix A). The following phase of dolomites (D2) yielded a range of values (0.708948 \pm 0.000007 to $0.709509 \pm 0.000007)$, which partially overlaps with that of D1 (Fig. 8), whereas the paragenetically late saddle dolomite has slightly lower values $(0.707905 \pm$ 0.000008 to $0.708899 \pm 0.000009)$ than those of D2.

\section{Discussion}

\section{Dolomite petrography}

The petrographic characteristics of the D1 (dolomicrite)
Fig. 5. Microthermometric data from fluid inclusions in the Aguathuna carbonates (D3, D2, and C3) showing (a) histograms of homogenization temperatures and $(b)$ homogenization temperature and final ice-melting temperature correlation scatter diagram.

(a)
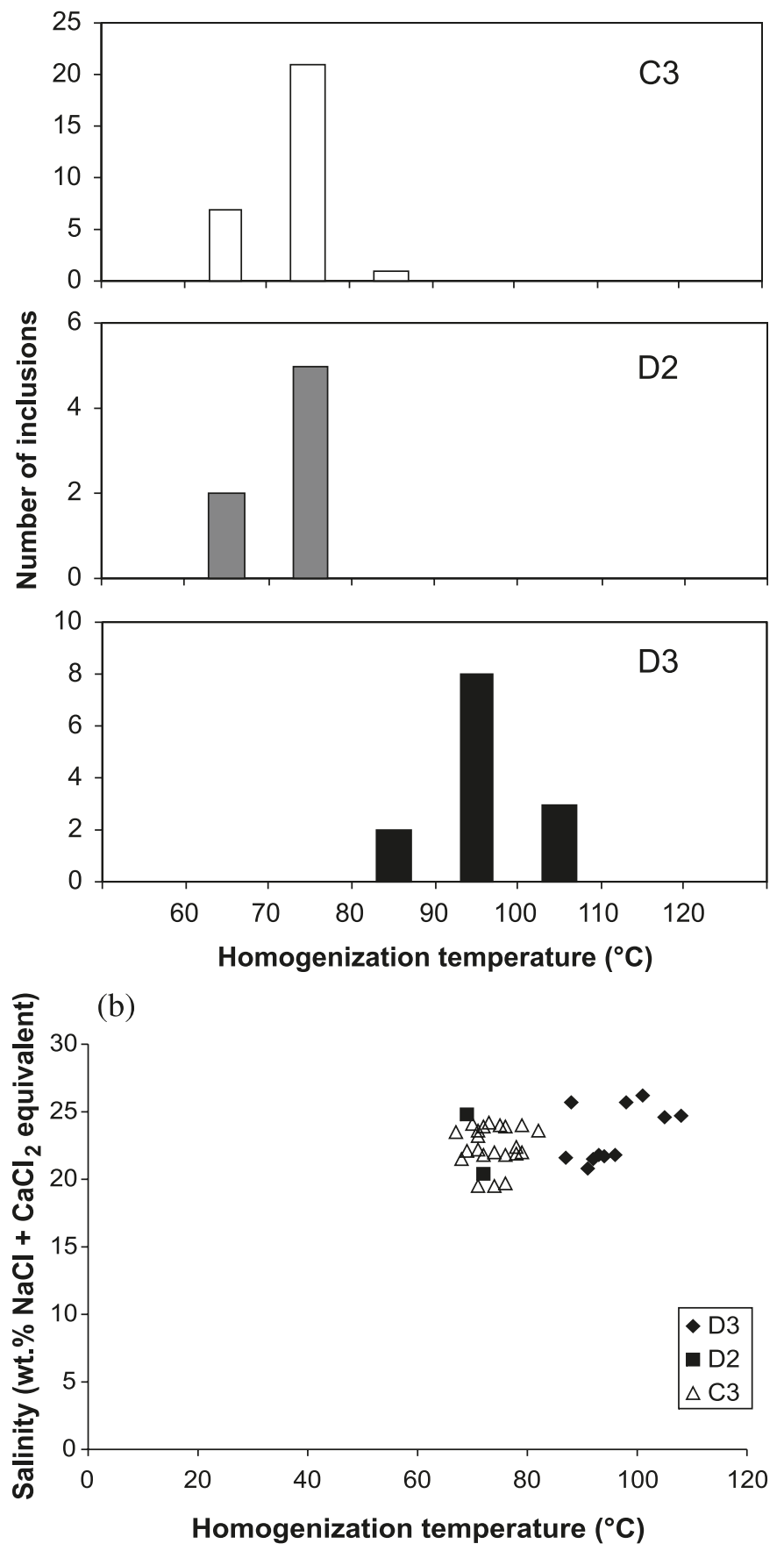

indicate a marine precursor limemud and fabric retention, which argues for an early very shallow-burial diagenetic event, whereas the characteristics of D2 may suggest a later stage of replacement but still at relatively shallow to intermediate burial depth. The dull luminescence of the late D3 (saddle dolomite) and the Fe-rich content as well as the cooccurrence of coarse euhedral pyrite crystals $(2-3 \mathrm{~mm})$ are likely indicative of deep-burial environments, where such 
Table 2. $\mathrm{CaCO}_{3}, \mathrm{MgCO}_{3}, \mathrm{Mn}, \mathrm{Sr}, \mathrm{Fe}, \delta^{18} \mathrm{O}$, and $\delta^{13} \mathrm{C}$ statistics for the Aguathuna carbonates.

\begin{tabular}{|c|c|c|c|c|c|c|c|c|}
\hline Phase & & $\mathrm{CaCO}_{3}(\%)$ & $\mathrm{MgCO}_{3}(\%)$ & $\mathrm{Sr}(\mathrm{ppm})$ & $\mathrm{Mn}(\mathrm{ppm})$ & $\mathrm{Fe}(\mathrm{ppm})$ & $\delta^{13} \mathrm{C}(\%$ VPDB $)$ & $\delta^{18} \mathrm{O}(\%$ VPDB $)$ \\
\hline \multirow[t]{5}{*}{$\mathrm{C} 1$} & $n$ & 8 & 8 & 8 & 8 & 8 & 11 & 11 \\
\hline & average & 98.4 & 1.6 & 300 & 78 & 710 & -1.3 & -7.1 \\
\hline & stdev & 1.5 & 1.5 & 154 & 66 & 434 & 0.8 & 0.6 \\
\hline & $\max$ & 99.4 & 5.0 & 653 & 229 & 1311 & -0.4 & -5.9 \\
\hline & $\min$ & 95.0 & 0.6 & 182 & 26 & 95 & -2.8 & -8.0 \\
\hline \multirow[t]{5}{*}{$\mathrm{C} 2$} & $n$ & 3 & 3 & 3 & 3 & 3 & 3 & 3 \\
\hline & average & 99.6 & 0.4 & 222 & 27 & 461 & -1.0 & -6.6 \\
\hline & stdev & 0.2 & 0.2 & 78 & 3 & 37 & 0.5 & 1.0 \\
\hline & $\max$ & 99.8 & 0.6 & 288 & 30 & 504 & -0.6 & -6.0 \\
\hline & $\min$ & 99.4 & 0.2 & 135 & 23 & 438 & -1.8 & -7.1 \\
\hline \multirow[t]{5}{*}{$\mathrm{C} 3$} & $n$ & 6 & 6 & 6 & 6 & 6 & 8 & 8 \\
\hline & average & 97.9 & 2.1 & 76 & 1218 & 891 & -3.0 & -10.9 \\
\hline & stdev & 2.4 & 2.4 & 15 & 721 & 418 & 0.3 & 2.0 \\
\hline & $\max$ & 99.6 & 6.7 & 93 & 2534 & 1630 & -2.5 & -8.1 \\
\hline & $\min$ & 93.3 & 0.4 & 53 & 440 & 422 & -3.4 & -13.0 \\
\hline \multirow[t]{5}{*}{ D1 } & $n$ & 19 & 19 & 19 & 19 & 19 & 27 & 27 \\
\hline & average & 55.4 & 44.6 & 92 & 314 & 1795 & -1.6 & -4.0 \\
\hline & stdev & 1.1 & 1.1 & 18 & 230 & 1117 & 0.5 & 0.6 \\
\hline & $\max$ & 58.3 & 47.0 & 129 & 836 & 4249 & -0.6 & -2.9 \\
\hline & $\min$ & 53.0 & 41.7 & 66 & 70 & 509 & -3.1 & -5.4 \\
\hline \multirow[t]{5}{*}{$\mathrm{D} 2$} & $n$ & 6 & 6 & 6 & 6 & 6 & 8 & 8 \\
\hline & average & 58.6 & 41.4 & 110 & 567 & 2612 & -1.0 & -5.6 \\
\hline & stdev & 4.9 & 4.9 & 59 & 308 & 930 & 0.5 & 0.5 \\
\hline & $\max$ & 68.3 & 44.5 & 196 & 1031 & 4090 & -0.2 & -5.0 \\
\hline & $\min$ & 55.5 & 31.7 & 62 & 261 & 1451 & -1.5 & -6.3 \\
\hline \multirow[t]{5}{*}{ D3 } & $n$ & 4 & 4 & 4 & 4 & 4 & 5 & 5 \\
\hline & average & 58.1 & 41.9 & 52 & 1555 & 7690 & -1.3 & -3.5 \\
\hline & stdev & 0.9 & 0.9 & 12 & 530 & 1153 & 0.1 & 0.2 \\
\hline & $\max$ & 59.4 & 42.7 & 68 & 1945 & 8368 & -1.2 & -3.3 \\
\hline & $\min$ & 57.3 & 40.6 & 42 & 774 & 5965 & -1.4 & -3.7 \\
\hline
\end{tabular}

saddle dolomite is commonly seen as an indicator, but yet equivocal, of a hydrothermal event (e.g., Lohmann and Walker 1989; Al-Aasm 2003, Lavoie et al. 2005; Lonnee and Machel 2006; Davies and Smith 2006). The CL images are distinct particularly for D2, which shows clear zoning (Fig. $4 g$ ) and may indicate that the chemistry of the diagenetic fluids varied during the course of dolomitization.

\section{Major and trace elements}

The calcium concentrations of the Aguathuna dolomites (D1 to D3) vary approximately from $\sim 53 \%$ to $68 \%$ (Table 2), as do modern dolomites (cf. Budd 1997; Warren 2000). This indicates that these dolomites are mainly nonstoichiometric (e.g., Budd 1997).

Trace element concentrations in dolomites, particularly those of $\mathrm{Sr}$, are used as fingerprint signatures to identify the nature and origin of the dolomitizing fluids (e.g., $\mathrm{Lu}$ and Meyers 1998). The $\mathrm{Sr} / \mathrm{Ca}$ molar ratio of the dolomitizing fluids can be calculated from the equation $(\mathrm{Sr} / \mathrm{Ca})_{\text {dolomite }}=$ $D_{\mathrm{Sr}}(\mathrm{Sr} / \mathrm{Ca})_{\text {fluid, }}$, where $D_{\mathrm{Sr}}$ is the distribution coefficient of $\mathrm{Sr}$ between the diagenetic fluids and the precipitated dolomite (Veizer 1983). The $D_{\mathrm{Sr}}$ estimate values for dolomite vary from 0.015 to 0.06 (Veizer 1983; Vahrenkamp and Stewart 1990; Banner 1995; Budd 1997), which may yield molar $\mathrm{Sr} / \mathrm{Ca}$ ratios for the Aguathuna dolomitizing fluids between $0.0056 \pm 0.0027$ for $D_{\mathrm{Sr}}=0.015$ and $0.0014 \pm 0.0007$ for $D_{\mathrm{Sr}}=0.06$. These values are significantly less than the molar $\mathrm{Sr} / \mathrm{Ca}$ ratio of present-day seawater (0.0086; Drever 1988), thus suggesting that the Aguathuna dolomitizing fluids were Sr-depleted, possibly with influx of Sr-poor meteoric waters (e.g., Azmy et al. 2001). Nonetheless, the uncertainty in $D_{\mathrm{Sr}}$ values of dolomite may imply some caution with these interpretations.

The Aguathuna dolomites, including the most Fe-enriched D3 phase (7690 $\pm 1153 \mathrm{ppm})$, have Fe contents of $<2 \mathrm{~mol} \%$ (Table 2; Appendix A), which indicate that they are nonferroan (Tucker and Wright 1990; Budd 1997). Unlike Sr, the $\mathrm{Mn}$ and $\mathrm{Fe}$ contents are monitors of the redox conditions during dolomitization. A general trend of increase in $\mathrm{Fe}$ and Mn contents from D1 to D3 and also from $\mathrm{C} 1$ to $\mathrm{C} 3$ (Fig. 6a) was caused by the prevailing reducing conditions with progressive burial.

The distribution of trace elements with depth may, in places, reveal an approximate outline for the direction of the diagenetic fluid circulation (e.g., Al-Aasm and Azmy 1996). This appears to be the case for the Aguathuna Formation dolomites (Fig. 9). The Aguathuna dolomites show a trend of slight increase of Sr contents with depth (Fig. 9) reflecting a progressive residual enrichment possibly caused by a relative downward circulation of the early diagenetic fluids through the rocks. The proposed circulation is also consistent with the porosity distribution pattern in the Aguathuna Formation of the investigated drill hole RND1 succession, where the upper beds are extensively dolomitized and less 
Fig. 6. Scatter diagrams of (a) Mn vs. Fe and (b) Mn vs. Sr for all carbonate phases in the Aguathuna Formation.
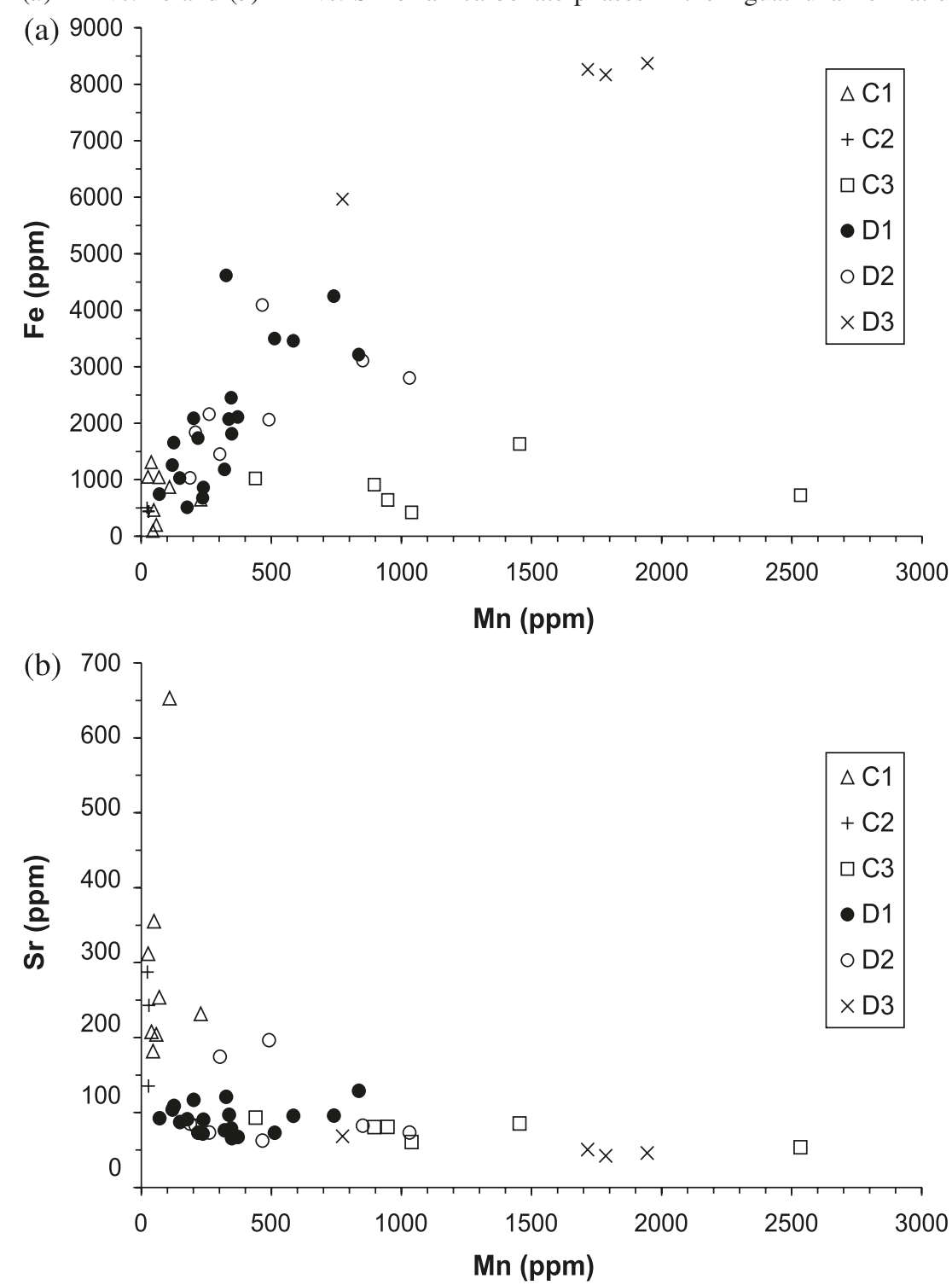

porous compared with the lower intervals, which have higher preserved porosity caused by less intensive dolomitization.

\section{Oxygen and carbon isotopes}

The $\delta^{13} \mathrm{C}$ values of the Aguathuna marine limemud (C1) and the paragenetically early dolomites (D1 and D2) show a narrow range of largely overlapping values within $<2.5 \%$ o (Fig. 7). The $\delta^{13} \mathrm{C}$ values of $\mathrm{D} 1$ and $\mathrm{D} 2$ dolomites likely mirror those of the precursor carbonates, due to relatively low $\mathrm{CO}_{2}$ content of the diagenetic waters (Land 1992). This may suggest a rock-buffered effect on early dolomite $\delta^{13} \mathrm{C}$ ratios. The $\delta^{18} \mathrm{O}$ values of $\mathrm{C} 3$ show a distinct depletion relative to those of $\mathrm{C} 1$ and $\mathrm{C} 2$ (Fig. 7), which is associated with the increase in temperature with progressive burial. The $\delta^{18} \mathrm{O}$ values, and $\delta^{13} \mathrm{C}$ values as well, of the micritic limemud (C1) almost invariably plot within the range of composition of the best preserved carbonates precipitated from the Arenig (Early to mid- Ordovician) seawater (Fig. 7), suggesting a high degree of preservation of their primary iso- topic signatures (cf. Veizer et al. 1999; Shields et al. 2003). In contrast, the $\delta^{18} \mathrm{O}$ values of the latest calcite cement (C3) are significantly depleted relative to the rest of the Aguathuna carbonates. This might suggest precipitation at high temperature or introduction of ${ }^{18} \mathrm{O}$-depleted meteoric waters. The high Th measurements and salinity estimates for C3 calcite (Table 1) strongly suggest a thermal effect under reducing conditions in the deep-burial realm, which is consistent with their remarkably high Mn contents (Fig. 6a). Although petrographic observations indicate that some $\mathrm{C} 3$-filled late fractures appear to crosscut D2 zones, which have pores filled with D3, the Th values of C3 are lower than those of the D3 (Table 1). This may suggest that C3 precipitated later than D3 possibly after a relative tectonic uplift. The $\delta^{18} \mathrm{O}$ values of the dolomicrite (D1) are more enriched relative to those of the limemud (C1) and, as expected, they fall outside the range of the well preserved Arenig marine carbonates (Fig. 7). Previous studies suggested that D1 originated from evaporative brines or syngenetically from ${ }^{18} \mathrm{O}$-enriched seawaters through evaporation in supratidal settings (Pratt 
Fig. 7. Scatter diagram of $\delta^{18} \mathrm{O}$ vs. $\delta^{13} \mathrm{C}$ for the different Aguathuna carbonate phases. The square represents the range of isotopic composition of best preserved carbonates precipitated from Arenig seawater (cf. Veizer et al. 1999 and Shields et al. 2003).

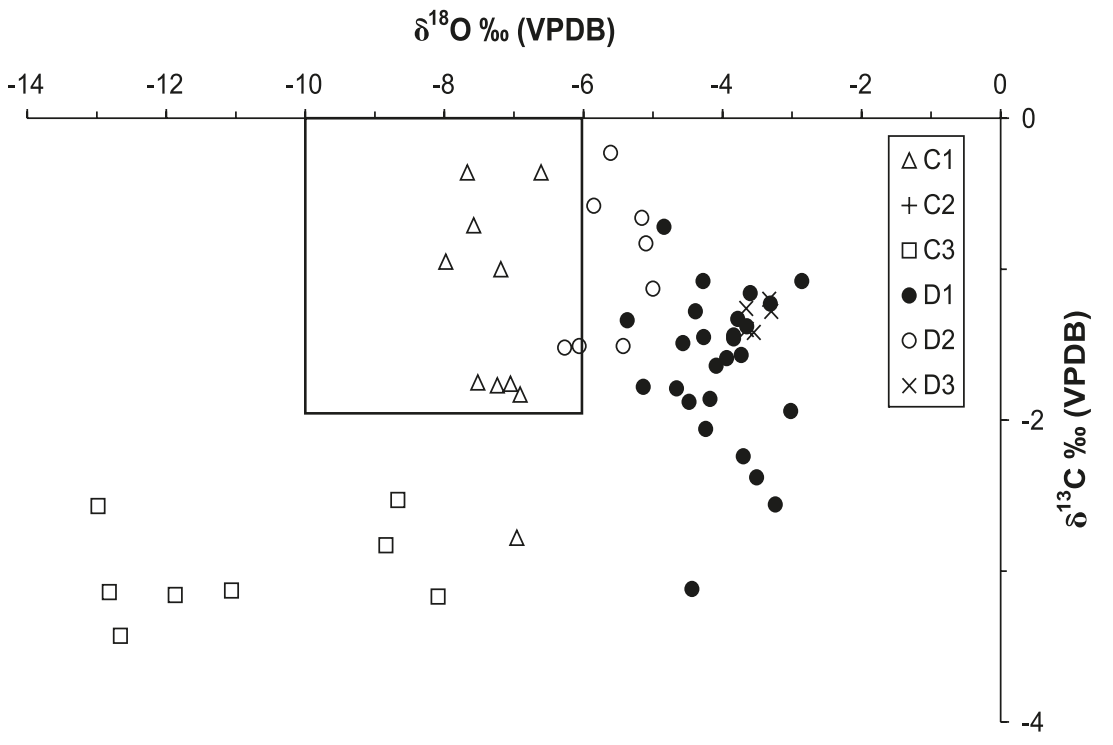

Fig. 8. Scatter diagram showing the distribution of ${ }^{87} \mathrm{Sr} /{ }^{86} \mathrm{Sr}$ values in the Aguathuna dolomites. The shaded area represents the ranges of primary ${ }^{87} \mathrm{Sr} /{ }^{86} \mathrm{Sr}$ values suggested for the Arenig (Early Ordovician) seawaters (cf. Veizer et al. 1999; Shields et al. 2003).

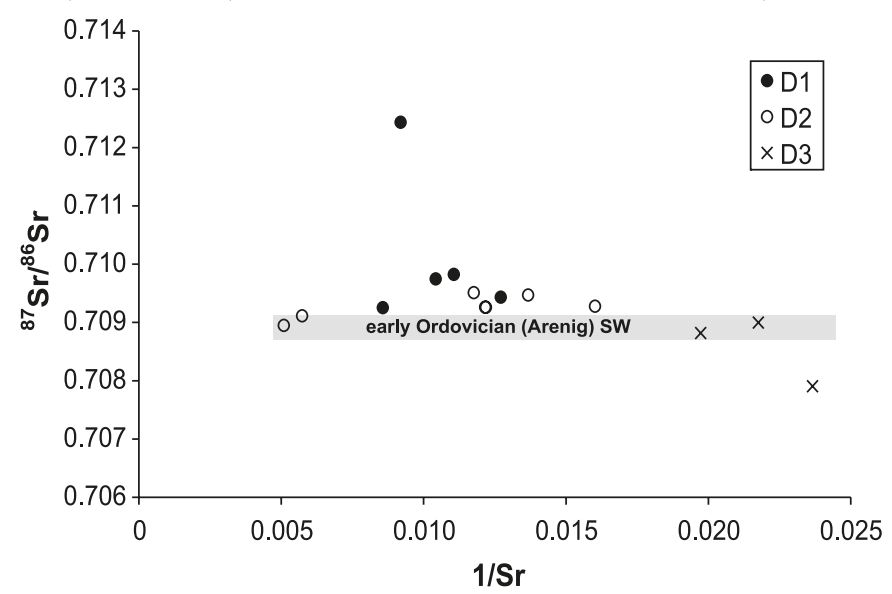

1979; Lane 1990). However, the low Sr contents in D1 $(91 \pm 18 \mathrm{ppm})$ and the absence of unequivocal evaporite beds in the Aguathuna Formation may strongly argue against the hypothesis of brine origin (cf. Meyers et al. 1997; Lu and Meyers 1998; Azmy et al. 2001). Saddle dolomites are commonly characterized by depleted $\delta^{18} \mathrm{O}$ signatures, relative to early diagenetic dolomites, due to precipitation at higher temperatures (Budd 1997; Davies and Smith 2006). However, the complex interplay between temperature (and the associated thermal isotopic fractionation effect) and the isotopic composition of the diagenetic fluid responsible for the saddle dolomite renders this general affirmation quite equivocal at times. The Aguathuna saddle dolomites (D3) have $\delta^{18} \mathrm{O}$ values of $-3.5 \%$. $0.2 \%$ (VPDB), which overlap with those of D1. The engulfed pyrite and the high homogenization ( $T h$ ) temperatures (up to $108{ }^{\circ} \mathrm{C}$ ) of the trapped primary two-phase fluid inclusions in D3 (Table 1), as well as the low melting temperatures
Fig. 9. Scatter diagram of depth of samples in Core RND1 vs. Sr content showing the trend of variation in D1 of Aguathuna carbonates.

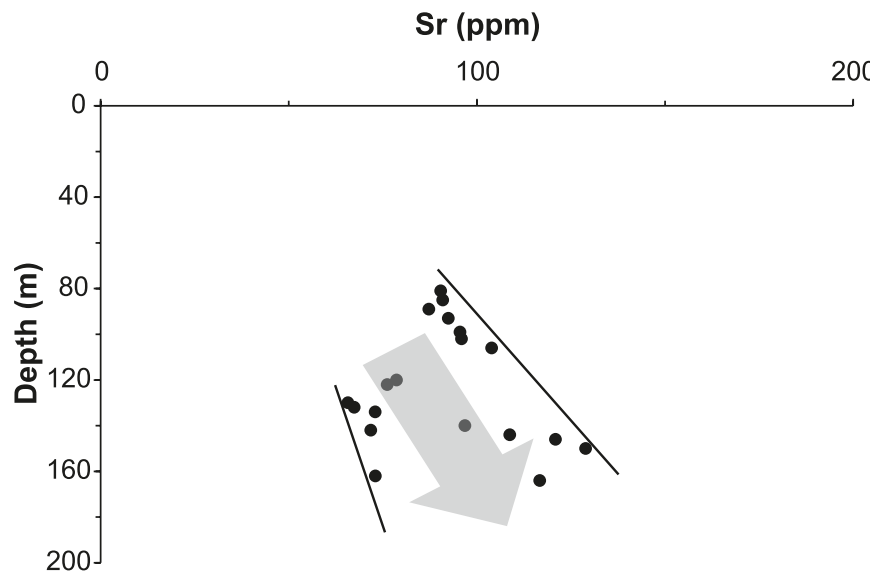

$\left(T \mathrm{~m}_{\text {ice }}=-31.3\right.$ to $\left.-17.4{ }^{\circ} \mathrm{C}\right)$ characteristic of high salinity (cf. Goldstein and Reynolds 1994), are consistent with possible hydrothermal origin.

Dolomitization of limestones requires a major supply of $\mathrm{Mg}$, and it, in turn, involves large volumes of Mg-rich water. Therefore, the oxygen isotopic composition of the dolomite is ultimately influenced by that of the dolomitizing fluid and the ambient temperature at the site of dolomite precipitation or replacement (Land 1992). Estimates of $\delta^{18} \mathrm{O}$ values of dolomitizing fluids can be calculated when temperature of dolomitization is established by other means such as measuring the homogenization temperatures of the trapped primary two-phase fluid inclusions in dolomites, which provide proxies of the temperature of dolomite precipitation. The fabric preservation in D1 indicates that dolomitization started during early stages of diagenesis, presumably at near-surface temperature of $\sim 25$ to $30{ }^{\circ} \mathrm{C}$ (cf. Goldstein and Reynolds 1994). Therefore, given the $\delta^{18} \mathrm{O}$ of D1 phase (Table 2), the $\delta^{18} \mathrm{O}$ values of the dolomitizing fluid for D1 were likely between $-5 \%$ and $-6 \%$ 
Fig. 10. Temperature $(T)$ vs. $\delta^{18} \mathrm{O}_{\text {diagenetic fluid }}$ for various $\delta^{18} \mathrm{O}_{\text {dolomite }}$ values that were reconstructed from the following equation: $10^{3} \ln \alpha=$ $3.2 \times 10^{6} T^{-2}-3.3$ (Land, 1983). The vertical bars indicate the ranges for $\delta^{18} \mathrm{O}_{\text {fluid }}$ based on the ranges of $\delta^{18} \mathrm{O}$ values and homogenization temperatures $(\mathrm{Th})$ of each identified dolomite generation.

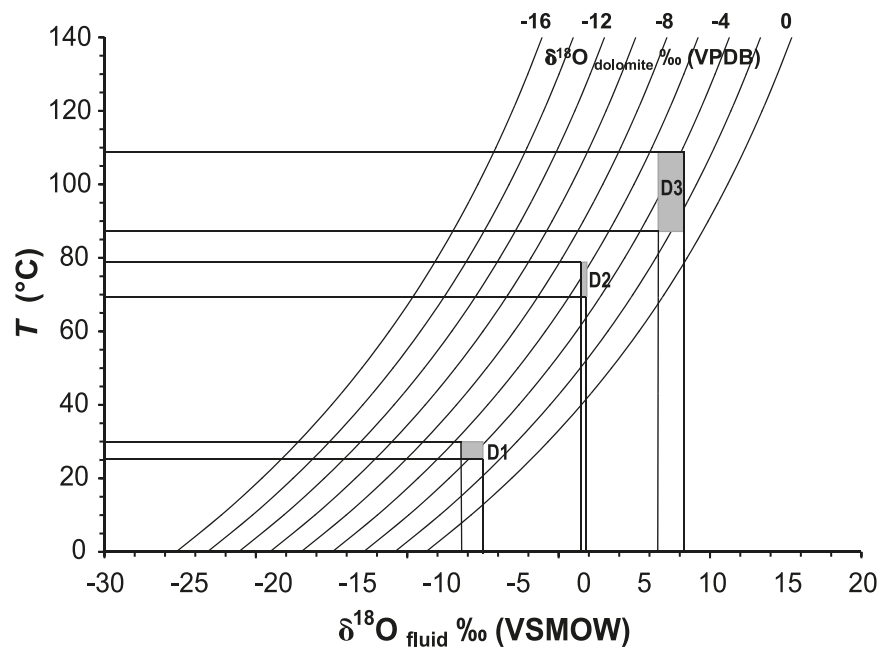

(Fig. 10). The occurrence of fenestral and stromatolitic lime mudstones (cf. Knight et al. 2007) and absence of evaporite interbeds in the Aguathuna succession indicate warm conditions of low latitude environments. In similar modern tropical environments $\left(\sim 25\right.$ to $\left.30{ }^{\circ} \mathrm{C}\right)$, the $\delta^{18} \mathrm{O}$ of seawater is $\sim 0 \%$ VSMOW (Vienna Standard Mean Ocean Water) (Muehlenbachs 1998) and that of meteoric water is lower by $\sim 4 \%$ (Clark and Fritz 1997). The estimated $\delta^{18} \mathrm{O}$ value of the Arenig seawater at the time of sedimentation of the Aguathuna shallow-marine facies is $\sim-2 \%$ to $-3 \%$ o VSMOW (Shields et al. 2003; Bassett et al. 2007). Assuming that the difference in $\delta^{18} \mathrm{O}_{\text {vsMow }}$ composition between the Arenig sea and meteoric waters was similar to our present-day environment and neglecting any unknown continental minor effects for the Early Ordovician epeiric seas bathing the Laurentia craton, the $\delta^{18} \mathrm{O}$ values of the Arenig meteoric waters would be $\sim-6 \%$ to $-7 \%$ VSMOW. Considering the uncertainty in the value of dolomite-calcite and dolomite-water fractionation factors (Land 1983, 1992; Budd 1997), the calculated $\delta^{18} \mathrm{O}$ estimates ( $-5 \%$ to $-6 \%$ VSMOW) for D1 fluids (Fig. 10) fall within the range of values suggested for the $\delta^{18} \mathrm{O}$ Arenig marine and meteoric waters $(-3 \%$ to $-7 \%$ VSMOW). Consequently, the suggested $\delta^{18} \mathrm{O}$ range of $-5 \%$ to $-6 \%$ VSMOW for fluids generating the D1 (Fig. 10) would be consistent with an early origin in the mixing zone, which agrees also with their elemental chemistry composition. This assumption is supported by the fabric preservation particularly in the dolomicrites (D1).

If D1 likely originated from mixed Early Ordovician marine and meteoric waters, the later dolomite phases, D2 and D3, were most likely derived from ${ }^{18} \mathrm{O}$-enriched fluids. Their average $T$ h values of the primary two-phase inclusions vary between $73.1 \pm 3.5$ and $95.2 \pm 6.3{ }^{\circ} \mathrm{C}$, respectively (Table 1). Given the $\delta^{18} \mathrm{O}$ ratios of D2 and D3 (Table 2), it follows that the fluids responsible for their formation had a $\delta^{18} \mathrm{O}$ composition that ranged from $+1 \%$ to $+2 \%$ VSMOW for D2 and from $+6 \%$ o to $+8 \%$ v VSMOW for D3 (Fig. 10).
Deep-basinal brines are commonly enriched in ${ }^{18} \mathrm{O}$ and are highly saline (cf. Goldstein and Reynolds 1994), which is consistent with the high salinities (Fig. 5b, Table 1) of D2 and D3 dolomites $(22.6 \pm 3.1$ and $23.3 \pm 2.1$ wt.\% $\mathrm{NaCl}$, respectively).

\section{Sr-isotope signatures}

Given the relative size of the respective strontium reservoirs, the Sr-isotope signature in diagenetic solutions (e.g., dolomitizing fluids) is usually controlled by that of the dissolving precursor phase (Veizer 1983; Banner 1995). Therefore, if diagenesis (dolomitization) started early, the ${ }^{87} \mathrm{Sr} /$ ${ }^{86} \mathrm{Sr}$ values of dolomite would likely reflect the $\mathrm{Sr}$-isotope composition of the original seawater, particularly if the dolomite occurred in a fabric-retentive succession that lacked clear evidence of later alteration. The temporal variations in Sr-isotope signatures of the Phanerozoic seawater were recently established by Veizer et al. (1999), based on wellpreserved low Mg-calcite shells, and also utilized for highresolution age estimates (e.g., Azmy et al. 1999). A recent study detailed the Ordovician Sr-isotope trend (Shields et al. 2003 and references therein) and showed a persistent decrease in the ${ }^{87} \mathrm{Sr} /{ }^{86} \mathrm{Sr}$ values through the Early to mid-Ordovician with a dramatic drop at the boundary between midand Late Ordovician (Shields et al. 2003, their fig. 6). This global ${ }^{87} \mathrm{Sr} /{ }^{86} \mathrm{Sr}$ pattern can be used to estimate the timing of dolomitization of the Aguathuna carbonates. The ${ }^{87} \mathrm{Sr} /{ }^{86} \mathrm{Sr}$ values of the earliest dolomite phase (D1) show insignificant correlation with their Sr contents (Fig. 8), suggesting a considerable degree of preservation of their primary signatures inherited from precursor calcites. Assuming that the least radiogenic ${ }^{87} \mathrm{Sr} /{ }^{86} \mathrm{Sr}$ ratio $(0.709251 \pm 0.000009$; Appendix A) of D1 is the best approximation of its precursor carbonate, a mid- to late Arenig modified seawater would be suggested for the early dolomitizing solutions (Fig. 8). Although the D2 and D3 phases have ${ }^{87} \mathrm{Sr} /{ }^{86} \mathrm{Sr}$ values that overlap with those of D1, it is unlikely that their values would reflect the signature of the seawater at the time of precipitation due to the alteration of the $\mathrm{Sr}$-isotope composition of the diagenetic fluids caused by complicated water-rock interactions during the circulation of the fluids through crustal rocks at deepburial settings. The relative grouping of the ${ }^{87} \mathrm{Sr} /{ }^{86} \mathrm{Sr}$ values of D1 and D2 (Fig. 8) might suggest that the dolomitizing fluids that led to the formation of D2 were genetically related to the D1 fluids, although some input of $\delta^{18} \mathrm{O}$ heavy basinal fluids is recognized. Additional data are, however, still needed to be more conclusive.

\section{Development of secondary porosity and reservoir potential}

The development of secondary porosity in carbonates is a significant issue in understanding the nature and evolution of hydrocarbon reservoirs. Post-depositional pores may form by different processes that vary from subaerial exposure and meteoric dissolution in early and near-surface diagenetic environments (e.g., Longman 1980) to neomorphism and replacement, such as dolomitization in burial environments (e.g., Dravis 1992; Esteban and Taberner 2003; Dravis and Muir 2004; Wierzbicki et al. 2006). The relative timing of the diagenetic alterations, including dolomitization, provides a better understanding of the relationships between the sec- 
ondary pores and the diagenetic features of carbonates, such as stylolitization, fractures, and mineralization. These relationships, along with geochemical investigations, help to better constrain the origin of diagenetic fluids and their circulation through altered carbonates, which are key controls on porosity evolution and distribution through reservoir rocks (e.g., Smith 2006; Wierzbicki et al. 2006).

The major subaerial exposure (St. George Unconformity) at the top of the Aguathuna Formation (Cooper et al. 2001) and significant meteoric dissolution are believed to have contributed to the later extensive dolomitization by increasing the available porosity and permeability of the underlying carbonates for efficient fluid circulation (Knight and James 1987; Baker and Knight 1993; Langdon and Mireault 2004). A reservoir unit was found in the Port au Port \#1 discovery well, which was drilled on the Port au Port Peninsula to the south of RND1 (Fig. 1). The reservoir unit has produced $\sim 3400 \mathrm{~m}^{3}$ of oil between 1995 and 2001 from the uppermost Aguathuna Formation (cf. Langdon and Mireault 2004), and recent testing of a sidetrack hole (Sidetrack \# 2) has resulted in a stabilized flow of $49.6 \mathrm{~m}^{3} /$ day (312 barrels). This reservoir consists of two main components: a low permeability matrix and a high permeability cavernous paleokarst component (Langdon and Mireault 2004). It is noteworthy that a first sidetrack well (\#1), within a radius of $50 \mathrm{~m}$ from Port au Port \#1 discovery, encountered nonporous and non-dolomitized limestones in the upper Aguathuna Formation (cf. Langdon and Mireault 2004). Similar lateral variations in the dolomitization and presence or absence of porosity is a common feature in hydrothermal dolomite fields (Davies and Smith 2006; Smith 2006).

The petrographic examination of the Aguathuna carbonates from the core RND1 indicates that the upper section of the Aguathuna carbonates are mostly nonporous dolomites, although high-porosity facies occur mainly in the lower part of the formation, associated with a later stage dolomitization (D2) of likely shallow-burial origin. No open caverns have been observed in the core material at the topmost layers of the formation immediately below the St. George Unconformity surface. This discrepancy can be explained by one or a combination of two possible scenarios: (1) the RND1 borehole missed those cavernous layers due to a significant lateral variation in the diagenetic features (rates of dissolution), and (or) (2) the major subaerial exposure (St. George Unconformity), along with faulting and tectonic uplift, most likely resulted in the loss of sedimentary sections with variable thickness across the upper Aguathuna outcrop, which may add to the complexity of lateral tracing and correlating the upper Aguathuna beds across boreholes.

Based on visual estimates from thin sections of the borehole RND1 samples, the porosity in Aguathuna dolomites varies from $<1 \%$ at the top of the formation to $\sim 10 \%$ in a dolomitized fenestral lime mudstone bed in the lowermost part of the investigated core (Fig. 4f; Appendix A). Some permeability measurements (Appendix A) on selected samples exhibit a similar trend with lower permeability $(\sim 1.1 \mathrm{mD})$ at the top of the formation but significantly higher values (up to $\sim 5.2 \mathrm{mD}$ ) at the bottom. Higher porosity (up to $18 \%$ ) and permeability (up to $317 \mathrm{mD}$ ) estimates have been documented particularly for the grainstone facies of the underlying Catoche dolomites (Baker and Knight
1993). The majority of pores in the Aguathuna dolomites are intercrystalline and mainly associated with the D2 replacement phase. Dissolution vugs with smooth boundaries also occur occasionally and are relatively larger, up to $2 \mathrm{~mm}$, in the lowest beds. Some of the large vugs were filled by C3 (late fracture-filling calcite cements) and D3 (late saddle dolomite).

The occlusion of most of the pore spaces in the upper Aguathuna dolomites suggests an efficient circulation of large volumes of dolomite-saturated diagenetic fluids, which resulted in extensive dolomitization and total occlusion of remaining primary and newly created secondary dissolution pore spaces. With progressive dolomitization, the dolomite saturation of fluids likely decreased downward, which resulted in adequate replacement of the precursor calcite in the lowermost beds but without extensive cementation of the intercrystalline spaces. The dolomitization of the upper Aguathuna Formation possibly occurred under open system conditions, which resulted in sealing most of the secondary and primary pore spaces. The rapidly sealed upper section of the Aguathuna Formation precluded an efficient circulation of the diagenetic fluids within the lower section of the formation, which resulted in dolomitization under limited local source for $\mathrm{Mg}^{+2}$ and $\mathrm{CO}_{3}{ }^{-2}$ ions. This dolomitization generated some intercrystalline pore space (Fig. 4f), which because of the presence of an efficient upper seal, had a higher potential of preservation (e.g., Weyl 1960; Warren 2000 , and references therein). The proposed downward circulation of the diagenetic fluids is consistent with the common occurrence of undolomitized limestone beds in the lower Aguathuna sequence (Fig. 2) and the relative increase in $\mathrm{Sr}$ concentrations with depth (Fig. 9).

Fractures caused by progressive burial or tectonic activities play, at times, a significant role in the permeability of carbonate reservoirs, and in particular for the hydrothermal dolomite plays (e.g., Davies and Smith 2006; Wierzbicki et al. 2006). Megascopic and petrographic examinations of the Aguathuna carbonates indicate that they have been exposed to fracturing that developed with progressive burial. However, all micro- and macro-fractures in the Aguathuna carbonates from RND1 are entirely occluded with $\mathrm{C} 3$, suggesting that they have no role in today's reservoir porosity.

In summary, petrographic examination and geochemical evidence from the Aguathuna carbonates suggest that the porosity and permeability distributions are strongly influenced by the degree of dolomitization. Except for the topmost porous layer immediately below the St. George Unconformity surface, porosity and permeability are generally very low in the upper beds, but both show significant downward increase. This pattern may suggest that the porous dolomites of the lower Aguathuna Formation, with the underlying Catoche limestones, and the nonporous sealing dolomites of the upper formation, are a potential diagenetic trap for possible hydrocarbon accumulations. The presence of a tight dolomite interval capping the porous reservoir is a well known fact in many hydrothermal fields in eastern North America (Smith 2006). Also, lateral variations in the diagenetic dissolution features and porosity distribution seem to be considerable in the Aguathuna Formation, another common and most problematic exploration fact for hydrothermal dolomite (Davies and Smith 2006; Smith 2006). 


\section{Conclusions}

Petrographic examinations, fluid inclusion investigations, trace element content, and stable isotope signatures of the Aguathuna carbonates suggest three major dolomitization events: (1) an early fabric-retentive episode (D1) that mainly affected the limemud, (2) a later replacive episode (D2) of mid-burial settings, and (3) a latest pore-filling to replacive saddle dolomite cements (D3) of deep-burial settings.

Petrographic examinations and visual porosity estimates along with the relationships of trace elements and depth suggest an early dominant downward circulation of dolomitizing fluid. Except for the topmost layer immediately below the St. George Unconformity, the downward-moving fluids extensively dolomitized the upper section of the Aguathuna Formation and resulted in significant reduction in rock porosity. However, the diagenetic strength of the dolomitizing fluids relatively decreased downward, which resulted in the development of intercrystalline pores that enhanced the total rock porosity in the lower section of the Aguathuna Formation. Late-burial vertical fractures were entirely occluded with late-burial calcite cements, likely derived from deepbasinal brines.

Petrography and fabric preservation in dolomicrites suggest that the first phase of dolomitization (D1) was initiated at early stage of diagenesis at temperatures below $50{ }^{\circ} \mathrm{C}$. Trace element chemistry and stable isotope results indicate that these dolomitizing fluids were a mixture of meteoric and sea waters, with $\delta^{18} \mathrm{O}$ estimated at about $-5 \%$ to $-6 \%$ (SMOW). However, later phases of dolomitization (D2 and D3) suggest formation under mid- to deep-burial conditions, respectively, at higher temperatures between 73 and $95{ }^{\circ} \mathrm{C}$ from ${ }^{18} \mathrm{O}$-enriched diagenetic fluids, most likely hot and saline brines. The occurrence of millimetre-scale euhedral pyrite crystals engulfed in the latest D3 phase is also consistent with a hydrothermal origin.

The least radiogenic ${ }^{87} \mathrm{Sr} /{ }^{86} \mathrm{Sr}$ signature obtained from the early dolomite (D1) is consistent with precipitation at an early stage around the Arenig.

\section{Acknowledgements}

The authors wish to thank Drs. I. Al-Aasm, H. Qing, F. $\mathrm{Lu}$, and J. Jisu for their time, efforts, and constructive reviews. This project was financed by the Earth Sciences Sector of Natural Resources Canada and by the Department of Natural Resources and Mines of Newfoundland and Labrador. Support from Vulcan Minerals Inc., Canada (to Karem Azmy), and by the Natural Sciences and Engineering Research Council of Canada (to Guoxiang Chi) is warmly acknowledged.

\section{References}

Al-Aasm, I. 2003. Origin and characterization of hydrothermal dolomite in the Western Canada Sedimentary Basin. Journal of Geochemical Exploration, 78-79: 9-15. doi:10.1016/S03756742(03)00089-X.

Al-Aasm, I.S., and Azmy, K. 1996. Diagenesis and evolution of microporosity of Middle-Upper Devonian Kee scarp reefs, Norman Wells, N.W.T, Canada: petrographic and chemical evidence. American Association of Petroleum Geologists Bulletin, 80: $82-100$.
Al-Aasm, I.S., and Clarke, J.D. 2004. The effect of hydrothermal fluid flow on early diagenetic dolomitization: an example from the Devonian Slave Point Formation, northwest Alberta, Canada. American Association of Petroleum Geologists Bulletin, Hedberg Series, 1: 297-316.

Azmy, K., Veizer, J., Wenzel, B., Bassett, M., and Copper, P. 1999. Silurian strontium isotope stratigraphy. Geological Society of America Bulletin, 111: 475-483. doi:10.1130/00167606(1999)111<0475:SSIS>2.3.CO;2.

Azmy, K., Veizer, J., Misi, A., De Olivia, T., and Dardenne, M. 2001. Isotope stratigraphy of the Neoproterozoic carbonate of Vazante Formation, Saõ Francisco Basin, Brazil. Precambrian Research, 112: 303-329. doi:10.1016/S0301-9268(01)00194-2.

Baker, D., and Knight, I. 1993. The Catoche dolomite project, Anticosti Basin, eastern Canada: CERR Report, Memorial University of Newfoundland, St. John's, Nfld., 174 p.

Banner, J.L. 1995. Application of the trace element and isotope geochemistry of strontium to studies of carbonate diagenesis. Sedimentology, 42: 805-824. doi:10.1111/j.1365-3091.1995. tb00410.x.

Bassett, D., Macleod, K.G., Miller, J.F., and Ethington, R.I. 2007. Oxygen isotopic composition of biogenic phosphate and the temperature of early Ordovician seawater. Palaios, 22: 98-103. doi:10.2110/palo.2005.p05-089r.

Budd, D.A. 1997. Cenozoic dolomites of carbonate islands: their attributes and origin. Earth-Science Reviews, 42: 1-47. doi:10. 1016/S0012-8252(96)00051-7.

Cawood, P.A., McCausland, P.J.A., and Dunning, G.R. 2001. Opening Iapetus: constraints from Laurentian margin in Newfoundland. Geological Society of America Bulletin, 113: 443453. doi:10.1130/0016-7606(2001)113<0443:OICFTL >2.0.CO;2.

Chi, G., and Ni, P. 2007. Equations for calculation of $\mathrm{NaCl} /(\mathrm{NaCl}$ $+\mathrm{CaCl}_{2}$ ) ratios and salinities from hydrohalite-melting and icemelting temperatures in the $\mathrm{H}_{2} \mathrm{O}-\mathrm{NaCl}-\mathrm{CaCl}_{2}$ system. Acta Petrologica Sinica, 23: 33-37.

Clark, I.D., and Fritz, P. 1997. Environmental isotopes in hydrogeology. Lewis Publisher, Boca Raton, Fla., 328 p.

Coleman, M.L., Walsh, J.N., and Benmore, R.A. 1989. Determination of both chemical and stable isotope composition in milligram-size carbonate samples. Sedimentary Geology, 65: 233238. doi:10.1016/0037-0738(89)90025-0.

Cooper, M., Weissenberger, J., Knight, I., Hostad, D., Gillespie, D., Williams, H., et al. 2001. Basin evolution in western Newfoundland: new insights from hydrocarbon exploration. American Association of Petroleum Geologists Bulletin, 85: 393-418.

Davies, G.R., and Smith, L.B. 2006. Structurally controlled hydrothermal dolomite reservoir: an overview. American Association of Petroleum Geologists Bulletin, 90: 1641-1690.

Dickson, J.A.D. 1966. Carbonate identification and genesis as revealed by staining. Journal of Sedimentary Petrology, 36: 491-505.

Dravis, J.J. 1992. Burial dissolution in limestones and dolomitescriteria for recognition and discussion of controls: a case study approach (part 1): Upper Jurassic Haynesville limestones, east Texas; part 2: Devonian Upper Elk Point dolomites, western Canada). American Association of Petroleum Geologists - Canadian Society of Petroleum Geologists, Short Course on subsurface dissolution porosity in carbonates, Calgary, Alta., $171 \mathrm{p}$.

Dravis, J.J., and Muir, I.D. 2004. Dolostone reservoirs created by burial dolomite dissolution: the Keg River case study, Comet Platform area, Rainbow Basin, NW Alberta, in Dolomites, the spectrum: mechanisms, models, reservoir development. Edited by J. Packard and G. Davies. Canadian Society of Petroleum Geology Core Conference, CD volume, Calgary, Alta., 58 p. 
Esteban, M., and Taberner, C. 2003. Secondary porosity development during late burial in carbonate reservoirs as a result of mixing and/or cooling of brines. Journal of Geochemical Exploration, 78-79: 355-359. doi:10.1016/S0375-6742(03) 00111-0.

Fowler, M.G., Hamblin, A.P., Hawkins, D., Stasiuk, L.D., and Knight, I. 1995. Petroleum geochemistry and hydrocarbon potential of Cambrian and Ordovician rocks of western Newfoundland. Bulletin of Canadian Petroleum Geology, 43: 187-213.

Goldstein, R.H., and Reynolds, T.J. 1994. Systematics of fluid inclusions in diagenetic minerals. SEPM (Society for Sedimentary Geology), Short Course 31, 199 p.

Haywick, D.W. 1984. Dolomite within the St. George Group (Lower Ordovician), western Newfoundland. Unpublished M.Sc. thesis, Memorial University of Newfoundland, St. John's, Nfld., 281 p.

Jacobi, R.D. 1981. Peripheral bulge-a causal mechanism for the Lower/Middle Ordovician unconformity along the western margin of the northern Appalachians. Earth and Planetary Science Letters, 56: 245-251. doi:10.1016/0012-821X(81)90131-X.

James, N.P., Stevens, R.K., Barnes, C.R., and Knight, I. 1989. Evolution of a Lower Paleozoic continental-margin carbonate platform, northern Canadian Appalachians. In Controls on carbonate platform and basin development. Edited by P.D. Crevello, J.L Wilson, J.F. Sarg, and J.F. Read. Society of Economic Paleontologists and Mineralogists, Special Publication 44, pp. 123-146.

Kamo, S.L., Gower, C.F., and Krogh, T.E. 1989. Birthdate for the Iapetus Ocean? A precise $\mathrm{U}-\mathrm{Pb}$ zircon and baddeleyite age for the Long Range dikes, southeast Labrador. Geology, 17: 602-605. doi:10.1130/0091-7613(1989)017<0602:BFTLOA>2.3.CO;2.

Kerans, C. 1989. Karst-controlled reservoir heterogeneity in Ellenburger Group carbonates of West Texas. American Association of Petroleum Geologists Bulletin, 72: 1160-1183.

Knight, I. 1991. Geology of Cambro-Ordovician rocks in the Port Saunders (NTS 12I/11), Castors River (NTS 12I/15), St. John Island (NTS 12I/14), and Torrent River (NTS 121/10) map areas. Newfoundland Department of Mines and Energy, Mineral Development Division, Report 91-4, 138 p.

Knight, I., and James, N.P. 1987. Stratigraphy of the St. George Group (Lower Ordovician), western Newfoundland: the interaction between eustasy and tectonics. Canadian Journal of Earth Sciences, 24: 1927-1952.

Knight, I., James, N.P., and Lane, T.E. 1991. The Ordovician St. George Unconformity, northern Appalachians: the relationship of plate convergence at the St. Lawrence Promontory to the Sauk/Tippecanoe sequence boundary. Geological Society of America Bulletin, 103: 1200-1225. doi:10.1130/00167606(1991)103<1200:TOSGUN>2.3.CO;2.

Knight, I., Azmy, K., Greene, M., and Lavoie, D. 2007. Lithostratigraphic setting of diagenetic, isotopic, and geochemistry studies of Ibexian and Whiterockian carbonates of the St. George and Table Head groups in western Newfoundland. Current Research, Newfoundland and Labrador Department of Natural Resources, Geological Survey Report 07-1, pp. 55-84.

Land, L.S. 1983. The application of stable isotopes to studies of the origin of dolomite and to problems of diagenesis of clastic sediments. In Stable isotopes in sedimentary geology. Edited by M.A. Arthur, T.F. Anderson, I.R. Kaplan, J. Veizer and L.S. Land. SEPM (Society for Sedimentary Geology), Short Course Notes 10, pp. 4-1-4-22.

Land, L.S. 1992. The dolomite problem: stable and radiogenic isotope clues. In Isotopic signature of sedimentary records. Edited by N. Clauer and S. Chaudhuri. Lecture Notes in Earth Science, 43, pp. 49-68.
Lane, T.E. 1990. Dolomitization, brecciation and zinc mineralization and their paragenetic, stratigraphic and structural relationships in the upper St. George Group (Ordovician) at Daniel's Harbour, western Newfoundland. Unpublished Ph.D. thesis, Memorial University of Newfoundland, St. John's, Nfld., 496 p.

Langdon, G.S., and Mireault, R. 2004. Revised exploration model for the inversion fairway, western Port au Port Peninsula, Newfoundland. A report for Canadian Imperial Venture Corp., St. John's, Nfld., 50 p. http://www.canadianimperial.net/

Lavoie, D. 2008. Appalachian foreland basin: 1-Canada. In Sedimentary basins of the USA and Canada. Edited by A. D. Miall. Elsevier Science Publishing, Amsterdam, The Netherlands. In press.

Lavoie, D. 1994. Diachronous tectonic collapse of the Ordovician continental margin, eastern Canada: comparison between the Quebec Reentrant and the St. Lawrence Promontory. Canadian Journal of Earth Sciences, 31: 1309-1319.

Lavoie, D., Chi, G., Brennan-Alpert, P., and Bertrand, R. 2005. Hydrothermal dolomitization in the Lower Ordovician Romaine Formation of the Anticosti Basin: significance for hydrocarbon exploration. Bulletin of Canadian Petroleum Geology, 53: 256269.

Lavoie, D., and Chi, G. 2006. Hydrothermal dolomitization in the Lower Silurian La Vielle Formation in northern New Brunswick: geological context and significance for hydrocarbon exploration. Bulletin of Canadian Petroleum Geology, 54: 380 395. doi:10.2113/gscpgbull.54.4.380.

Lohmann, K.C., and Walker, J.C.G. 1989. The $\delta^{18}$ O record of Phanerozoic abiotic marine calcite cements. Geophysical Research Letters, 16: 319-322. doi:10.1029/GL016i004p00319.

Longman, M.W. 1980. Carbonate diagenetic textures from nearsurface diagenetic environments. American Association of Petroleum Geologists Bulletin, 64: 461-487.

Lonnee, J., and Machel, H.G. 2006. Pervasive dolomitization with subsequent hydrothermal alteration in the Clarke Lake gas field, Middle Devonian Slave Point Formation, British Columbia, Canada. American Association of Petroleum Geologists Bulletin, 90: $1739-1761$.

Loucks, R.G. 2003. Origin of Lower Ordovician Ellenburger Group brecciated and fractured reservoirs in West Texas: paleocave, thermobaric, tectonic or all of the above? Annual Meeting, American Association of Petroleum Geologists, Expanded Abstracts, Vol. 12, p. 107.

Lu, F.H., and Meyers, W.J. 1998. Massive dolomitization of Late Miocene carbonate platform: a case of mixed evaporative brines with meteoric water, Nijar, Spain. Sedimentology, 45: 263-277. doi:10.1046/j.1365-3091.1998.0142e.x.

Machel, H.G., and Mountjoy, E.W. 1986. Chemistry and environments of dolomitization: a reappraisal. Earth-Science Reviews, 23: 175-202. doi:10.1016/0012-8252(86)90017-6.

Machel, H.G., and Mountjoy, E.W. 1990. Coastal mixing zone dolomite, forward modeling, and massive dolomitization of platform-margin carbonate; Discussion. Journal of Sedimentary Petrology, 60: 1008-1012.

McArthur, J.M. 1994. Recent trends in strontium isotope stratigraphy. Terra Nova, 6: 331-358. doi:10.1111/j.1365-3121.1994. tb00507.x.

Meyers, W.J., Lu, F.H., and Zachariah, J.K. 1997. Dolomitization by mixed evaporative brines and freshwater, Upper Miocene carbonates, Nijar, Spain. Journal of Sedimentary Research, 67: 898-912.

Muehlenbachs, K. 1998. The oxygen isotopic composition of the oceans, sediments and the seafloor. Chemical Geology, 145: 263-273. doi:10.1016/S0009-2541(97)00147-2. 
Mussman, W.J., and Read, J.G. 1986. Sedimentology and development of a passive margin unconformity: Middle Ordovician Knox Unconformity, Virginia Appalachians. Geological Society of America Bulletin, 97: 282-295. doi:10.1130/0016-7606(1986) 97<282:SADOAP>2.0.CO;2.

Pratt, B.R. 1979. The St. George Group (Lower Ordovician), western Newfoundland: sedimentology, diagenesis and cryptalgal structures. Unpublished M.Sc. thesis, Memorial University of Newfoundland, St. John's, Nfld., 254 p.

Pratt, B.R., and James, N.P. 1986. The tidal flat island model for peritidal shallow-upward sequences; St. George Group, western Newfoundland. Sedimentology, 33: 313-344. doi:10.1111/j. 1365-3091.1986.tb00540.x.

Quinn, L. 1995. Middle Ordovician foredeep fill in western Newfoundland. In Current perspective in the Appalachian-Caledonian orogen. Edited by J.P. Hibbard, C. van Staal, and P.A. Cawood. Geological Association of Canada, Special Paper 41, pp. 43-64.

Shields, G.A., Carden, G.A.F., Veizer, J., Meidla, T., Rong, J.-Y., and Li, R.-Y. 2003. Sr, C, and O isotope geochemistry of Ordovician brachiopods: a major isotopic event around the MiddleLate Ordovician transition. Geochimica et Cosmochimica Acta, 67: 2005-2025. doi:10.1016/S0016-7037(02)01116-X.

Sibley, D.F. 1982. Origin of common dolomite fabrics: clues from the Pliocene. Journal of Sedimentary Petrology, 52: 1087-1100.

Smith, L.B. 2006. Origin and reservoir characteristics of Upper Ordovician Trenton - Black River hydrothermal dolomite reservoirs in New York. American Association of Petroleum Geologists, 90: 1691-1718.

Stenzel, S.R., Knight, I., and James, N.P. 1990. Carbonate platform to foreland basin: revised stratigraphy of the Table Head Group (Middle Ordovician), western Newfoundland. Canadian Journal of Earth Sciences, 27: 14-26.

Stockmal, G.S., Slingsby, A., and Waldron, J.W.F. 1998. Deformation styles at the Appalachian structural front, western Newfoundland: implications of new industry seismic reflection data. Canadian Journal of Earth Sciences, 35: 1288-1306. doi:10. 1139/cjes-35-11-1288.

Tucker, M.E., and Wright, V.P. 1990. Carbonate Sedimentology. Blackwell Publishing, Oxford, UK., 482 p.

Vahrenkamp, V.C., and Stewart, P.K. 1990. A new distribution coefficient for the incorporation of strontium into dolomite and its implications for the formation of ancient dolomites. Geology, 18: 387-391. doi:10.1130/0091-7613(1990)018<0387:NDCFTI >2.3. $\mathrm{CO} ; 2$.

van Staal, C.R. 2005. The northern Appalachians. Edited by R.C.
Selley, L. Robin, M. Cocks, and I.R. Plimer. Elsevier, Oxford, UK., Encyclopedia of Geology, Vol. 4, pp. 81-91.

Veizer, J. 1983. Chemical diagenesis of carbonates. In Theory and application of trace element technique. Edited by M.A. Arthur, T.F. Anderson, I.R. Kaplan, J. Veizer, and L.S. Land. Stable Isotopes in Sedimentary Geology. SEPM (Society for Sedimentary Geology), Short Course Notes 10, pp. III-1-III-100.

Veizer, J., Ala, D., Azmy, K., Bruckschen, P., Bruhn, F., Buhl, D., et al. 1999. ${ }^{87} \mathrm{Sr} /{ }^{86} \mathrm{Sr}, \delta^{18} \mathrm{O}$ and $\delta^{13} \mathrm{C}$ evolution of Phanerozoic seawater. Chemical Geology, 161: 59-88. doi:10.1016/S00092541(99)00081-9.

Waldron, J.W.F., and van Staal, C.R. 2001. Taconian orogeny and the accretion of the Dashwoods block: a peri-Laurentian microcontinent in the Iapetus Ocean. Geology, 29: 811-814. doi:10. 1130/0091-7613(2001)029<0811:TOATAO >2.0.CO;2.

Waldron, J.W.F., Stockmal, G.S., Corney, R.E., and Stenzel, S.R. 1993. Basin development and inversion at the Appalachian structural front, Port au Port Peninsula, western Newfoundland Appalachians. Canadian Journal of Earth Sciences, 30: 1759-1772.

Warren, J. 2000. Dolomite: occurrence, evolution, and economically important associations. Earth-Science Reviews, 52: 1-81. doi:10.1016/S0012-8252(00)00022-2.

Westminer Canada Ltd. 1992. Drill logs for RND 001 and RND 002 holes, Port au Port Peninsula.

Weyl, P.K. 1960. Porosity through dolomitization: conservation of mass requirements. Journal of Sedimentary Petrology, 30: 8590.

White, T., and Al-Aasm, I.S. 1997. Hydrothermal dolomitization of the Mississippian Upper Debolt Formation, Sikanni gas field, northern British Columbia, Canada. Bulletin of Canadian Petroleum Geology, 45: 297-316.

Wierzbicki, R., Dravis, J.J., Al-Aasm, I., and Harland, N. 2006. Burial dolomitization and dissolution of Upper Jurassic Abenaki platform carbonates, Deep Panuke reservoir, Nova Scotia, Canada. American Association of Petroleum Geologists Bulletin, 90: $1843-1861$.

Wilson, J.L., Medlock, P.L., Fritz, R.D., Canter, K.L., and Geesaman, R.G. 1992. A review of Cambro-Ordovician breccias in North America. In Paleokarst, karst-related diagenesis and reservoir development. Edited byM.P. Candelaria and C.L. Reed. SEPM (Society for Sedimentary Geology) Permian Basin Section, Publication 92-33, pp. 19-29.

\section{Appendix A}

[Appendix table on following page.] 
Table A1. Samples, description, elemental and isotopic geochemical compositions, visual porosity estimates, and permeability in the Aguathuna carbonates.

\begin{tabular}{|c|c|c|c|c|c|c|c|c|c|c|c|c|c|}
\hline Field ID & Phase & $\begin{array}{l}\text { Depth } \\
(\mathrm{m})\end{array}$ & $\begin{array}{l}\mathrm{CaCO}_{3} \\
(\%)\end{array}$ & $\begin{array}{l}\mathrm{MgCO}_{3} \\
(\%)\end{array}$ & $\begin{array}{l}\mathrm{Sr} \\
(\mathrm{ppm})\end{array}$ & $\begin{array}{l}\mathrm{Mn} \\
(\mathrm{ppm})\end{array}$ & $\begin{array}{l}\mathrm{Fe} \\
(\mathrm{ppm})\end{array}$ & $\begin{array}{l}\delta^{18} \mathrm{O}(\% \\
\mathrm{VPDB})\end{array}$ & $\begin{array}{l}\delta^{13} \mathrm{C}(\% \\
\mathrm{VPDB})\end{array}$ & ${ }^{87} \mathrm{Sr} /{ }^{86} \mathrm{Sr}$ & $\pm 2 \sigma$ & $\begin{array}{l}\text { Visual estimate } \\
\text { of porosity }(\%)\end{array}$ & $\begin{array}{l}\text { Permeability } \\
(\mathrm{mD})\end{array}$ \\
\hline KAR1-081 & D1 & 81.0 & 55.72 & 44.28 & 90 & 239 & 860 & -3.2 & -2.6 & 0.709824 & 0.000008 & $<1$ & \\
\hline KAR1-083 & D1 & 83.0 & & & & & & -3.5 & -2.4 & & & & 1.1 \\
\hline KAR1-085 & D1 & 85.0 & 55.38 & 44.62 & 91 & 177 & 509 & -3.7 & -2.2 & & & & \\
\hline KAR1-087 & D1 & 87.0 & & & & & & -3.9 & -1.6 & & & & 1.9 \\
\hline KAR1-089 & D1 & 89.0 & 54.95 & 45.05 & 87 & 149 & 1029 & -4.2 & -1.9 & & & $<1$ & \\
\hline KAR1-091 & D1 & 91.0 & & & & & & -2.9 & -1.1 & & & $<1$ & 1.8 \\
\hline KAR1-093 & D1 & 93.0 & 54.82 & 45.18 & 92 & 70 & 744 & -3.8 & -1.4 & & & & \\
\hline KAR1-095 & D1 & 95.0 & & & & & & -4.2 & -2.1 & 0.710496 & 0.000007 & & \\
\hline KAR1-099 & D1 & 99.0 & 56.07 & 43.93 & 96 & 585 & 3459 & -4.4 & -3.1 & & & & \\
\hline KAR1-102 & D1 & 102.0 & 53.02 & 46.98 & 96 & 741 & 4249 & -4.7 & -1.8 & 0.709746 & 0.000008 & $<1$ & \\
\hline KAR1-106 & D1 & 106.0 & 55.76 & 44.24 & 104 & 120 & 1259 & -4.1 & -1.6 & & & & \\
\hline KAR1-108 & D1 & 108.0 & & & & & & -4.5 & -1.9 & & & & \\
\hline KAR1-110 & $\mathrm{C} 1$ & 110.0 & 99.17 & 0.83 & 204 & 58 & 199 & -7.0 & -2.8 & & & & \\
\hline KAR1-112 & $\mathrm{C} 1$ & 112.0 & 95.03 & 4.97 & 653 & 109 & 871 & -7.1 & -1.8 & & & & \\
\hline KAR1-118 & D1 & 118.0 & & & & & & -5.4 & -1.3 & & & $<1$ & \\
\hline KAR1-120 & D1 & 120.0 & 56.48 & 43.52 & 79 & 346 & 2450 & -4.6 & -1.5 & 0.709431 & 0.000012 & $<1$ & \\
\hline KAR1-122 & D1 & 122.0 & 55.53 & 44.47 & 76 & 320 & 1182 & -3.8 & -1.5 & & & $<1$ & \\
\hline KAR1-124 & $\mathrm{C} 1$ & 124.0 & 99.44 & 0.56 & 182 & 45 & 95 & -6.9 & -1.8 & & & & \\
\hline KAR1-128 & D1 & 128.0 & & & & & & -5.1 & -1.8 & & & & \\
\hline KAR1-130 & D1 & 130.0 & 55.10 & 44.90 & 66 & 348 & 1813 & -3.7 & -1.4 & & & & \\
\hline KAR1-132 & D1 & 132.0 & & & & & & -3.8 & -1.3 & & & & \\
\hline KAR1-134 & D1 & 134.0 & & & & & & -3.0 & -1.9 & & & & \\
\hline KAR1-136 & $\mathrm{C} 1$ & 136.0 & 99.34 & 0.66 & 355 & 48 & 464 & -7.2 & -1.8 & & & & \\
\hline KAR1-138 & D1 & 138.0 & & & & & & -3.3 & -1.2 & & & $<1$ & 1.4 \\
\hline KAR1-142 & D1 & 142.0 & 54.73 & 45.27 & 72 & 237 & 676 & -3.7 & -1.6 & & & & \\
\hline KAR1-144 & D1 & 144.0 & 54.86 & 45.14 & 109 & 126 & 1656 & -4.3 & -1.5 & 0.712434 & 0.00001 & & \\
\hline KAR1-146 & D1 & 146.0 & & & & & & -4.4 & -1.3 & & & $<1$ & \\
\hline KAR1-148 & D1 & 148.0 & & & & & & -3.6 & -1.2 & & & 3 & \\
\hline KAR1-150 & D1 & 150.0 & 58.29 & 41.71 & 129 & 836 & 3215 & -4.3 & -1.1 & & & & \\
\hline KAR1-154 & $\mathrm{C} 1$ & 154.0 & & & & & & -6.6 & -0.4 & & & 1 & 1.7 \\
\hline KAR1-160 & $\mathrm{C} 1$ & 160.0 & 97.36 & 2.64 & 232 & 229 & 646 & -7.5 & -1.8 & & & & \\
\hline KAR1-162 & D1 & 162.0 & 55.34 & 44.66 & 73 & 219 & 1736 & -4.8 & -0.7 & & & $<1$ & 5.2 \\
\hline KAR1-164 & D1 & 164.0 & 55.13 & 44.87 & 117 & 202 & 2087 & -3.9 & -0.6 & 0.709251 & 0.000009 & $<1$ & \\
\hline KAR1-166 & $\mathrm{C} 1$ & 166.0 & 99.24 & 0.76 & 312 & 26 & 1051 & -8.0 & -1.0 & & & & \\
\hline KAR1-168 & $\mathrm{C} 1$ & 168.0 & 99.43 & 0.57 & 254 & 69 & 1044 & -7.6 & -0.7 & & & & \\
\hline KAR1-172 & $\mathrm{C} 1$ & 172.0 & 98.32 & 1.68 & 208 & 39 & 1311 & -7.2 & -1.0 & & & 1 & 1.3 \\
\hline KAR1-174 & $\mathrm{C} 1$ & 174.0 & & & & & & -7.7 & -0.4 & & & & \\
\hline KAR1-176 & $\mathrm{C} 1$ & 176.0 & & & & & & -5.9 & -0.6 & & & & \\
\hline KAR1-114-2 & D2 & 114.0 & 56.60 & 43.40 & 73 & 1031 & 2800 & -6.3 & -1.5 & 0.709469 & 0.000009 & 3 & \\
\hline KAR1-116-2 & D2 & 116.0 & & & & & & -5.4 & -1.5 & 0.709509 & 0.000007 & 4 & \\
\hline KAR1-126-2 & D2 & 126.0 & 56.19 & 43.81 & 73 & 261 & 2160 & -6.1 & -1.5 & & & & \\
\hline KAR1-152-2 & D2 & 152.0 & 55.49 & 44.51 & 62 & 466 & 4090 & -5.0 & -1.1 & 0.709276 & 0.000007 & 3 & \\
\hline
\end{tabular}


Table A1 (concluded).

\begin{tabular}{|c|c|c|c|c|c|c|c|c|c|c|c|c|c|}
\hline Field ID & Phase & $\begin{array}{l}\text { Depth } \\
\text { (m) }\end{array}$ & $\begin{array}{l}\mathrm{CaCO}_{3} \\
(\%)\end{array}$ & $\begin{array}{l}\mathrm{MgCO}_{3} \\
(\%)\end{array}$ & $\begin{array}{l}\mathrm{Sr} \\
(\mathrm{ppm})\end{array}$ & $\begin{array}{l}\mathrm{Mn} \\
(\mathrm{ppm})\end{array}$ & $\begin{array}{l}\mathrm{Fe} \\
(\mathrm{ppm})\end{array}$ & $\begin{array}{l}\delta^{18} \mathrm{O}(\% \\
\mathrm{VPDB})\end{array}$ & $\begin{array}{l}\delta^{13} \mathrm{C}(\% \\
\mathrm{VPDB})\end{array}$ & ${ }^{87} \mathrm{Sr} /{ }^{86} \mathrm{Sr}$ & $\pm 2 \sigma$ & $\begin{array}{l}\text { Visual estimate } \\
\text { of porosity }(\%)\end{array}$ & $\begin{array}{l}\text { Permeability } \\
(\mathrm{mD})\end{array}$ \\
\hline KAR1-162-2 & D2 & 162.0 & & & & & & -5.1 & -0.8 & 0.709258 & 0.000008 & 3 & \\
\hline KAR1-168-2 & D2 & 168.0 & 59.26 & 40.74 & 196 & 492 & 2062 & -5.2 & -0.7 & 0.708948 & 0.000007 & & \\
\hline KAR1-170-2 & D2 & 170.0 & 55.87 & 44.13 & 82 & 852 & 3108 & -5.6 & -0.2 & 0.709260 & 0.000007 & 10 & 2.9 \\
\hline KAR1-176-2 & D2 & 176.0 & 68.26 & 31.74 & 174 & 302 & 1451 & -5.9 & -0.6 & 0.709113 & 0.000008 & & \\
\hline KAR1-147.7-D3 & D3 & 147.7 & 58.12 & 41.88 & 46 & 1945 & 8368 & -3.7 & -1.4 & 0.708999 & 0.000009 & & \\
\hline $\begin{array}{l}\text { KAR1-147.7- } \\
\text { D3b }\end{array}$ & D3 & 147.7 & 59.43 & 40.57 & 51 & 1716 & 8261 & & & 0.708818 & 0.000007 & & \\
\hline KAR1-147.8-D3 & D3 & 147.8 & 57.27 & 42.73 & 42 & 1785 & 8166 & -3.6 & -1.4 & 0.707905 & 0.000008 & & \\
\hline KAR1-148-D3 & D3 & 148.0 & & & & & & -3.3 & -1.3 & & & & \\
\hline KAR1-148-D3a & D3 & 148.0 & 57.72 & 42.28 & 68 & 774 & 5965 & -3.3 & -1.2 & & & & \\
\hline KAR1-148-D3b & D3 & 148.0 & & & & & & -3.7 & -1.3 & & & & \\
\hline KAR1-79-C2 & $\mathrm{C} 2$ & 79.0 & 99.5 & 0.5 & 243 & 30 & 441 & -6.0 & -0.6 & & & & \\
\hline KAR1-124-C2 & $\mathrm{C} 2$ & 124.0 & 99.8 & 0.2 & 135 & 28 & 438 & -7.1 & -1.8 & & & & \\
\hline KAR1-166-C2 & $\mathrm{C} 2$ & 166.0 & 99.4 & 0.6 & 288 & 23 & 504 & -6.6 & -0.7 & & & & \\
\hline KAR1-010-3 & $\mathrm{C} 3$ & 10.0 & 99.62 & 0.38 & 53 & 2534 & 725 & -8.1 & -3.2 & & & & \\
\hline KAR1-083-3 & $\mathrm{C} 3$ & 83.0 & 99.53 & 0.47 & 81 & 948 & 640 & -13.0 & -2.6 & & & & \\
\hline KAR1-091-3 & $\mathrm{C} 3$ & 91.0 & 98.47 & 1.53 & 93 & 440 & 1020 & -8.8 & -2.8 & & & & \\
\hline KAR1-099-3 & $\mathrm{C} 3$ & 99.0 & 97.34 & 2.66 & 80 & 896 & 910 & -12.7 & -3.4 & & & & \\
\hline KAR1-102-3 & $\mathrm{C} 3$ & 102.0 & 93.34 & 6.66 & 85 & 1455 & 1630 & -11.1 & -3.1 & & & & \\
\hline KAR1-104-3 & $\mathrm{C} 3$ & 104.0 & & & & & & -12.8 & -3.1 & & & & \\
\hline KAR1-116-3 & $\mathrm{C} 3$ & 116.0 & 99.29 & 0.71 & 61 & 1039 & 422 & -11.9 & -3.2 & & & & \\
\hline KAR1-176-3 & $\mathrm{C} 3$ & 176.0 & & & & & & -8.7 & -2.5 & & & & \\
\hline
\end{tabular}

$\stackrel{D}{N}$
$\stackrel{3}{3}$
$\stackrel{D}{1}$
$\stackrel{0}{=}$

Note: D1, dolomicrite, earliest dolomite phase; D2, middle dolomite phase; D3, latest dolomite phase; C1, micrite; C2, early equant meteoric cement; and C3, fracture-filling calcite cement. 